NBER WORKING PAPER SERIES

\title{
ABILITY, GENDER, AND PERFORMANCE STANDARDS: EVIDENCE FROM ACADEMIC PROBATION
}

\author{
Jason M. Lindo \\ Nicholas J. Sanders \\ Philip Oreopoulos \\ Working Paper 14261 \\ http://www.nber.org/papers/w14261 \\ NATIONAL BUREAU OF ECONOMIC RESEARCH \\ 1050 Massachusetts Avenue \\ Cambridge, MA 02138 \\ August 2008
}

We thank Chris Ayres, Scott Carrell, Doug Miller, Marianne Page, Ann Huff Stevens, and seminar participants at the UC Davis Applied Microeconomics Lunch Series, the 2008 WEAI Conference, and the University of British Columbia for their helpful comments and suggestions at various stages of this paper. The views expressed herein are those of the author(s) and do not necessarily reflect the views of the National Bureau of Economic Research.

NBER working papers are circulated for discussion and comment purposes. They have not been peerreviewed or been subject to the review by the NBER Board of Directors that accompanies official NBER publications.

(C) 2008 by Jason M. Lindo, Nicholas J. Sanders, and Philip Oreopoulos. All rights reserved. Short sections of text, not to exceed two paragraphs, may be quoted without explicit permission provided that full credit, including $(\odot)$ notice, is given to the source. 
Ability, Gender, and Performance Standards: Evidence from Academic Probation

Jason M. Lindo, Nicholas J. Sanders, and Philip Oreopoulos

NBER Working Paper No. 14261

August 2008

JEL No. D80,I20

\begin{abstract}
$\underline{\text { ABSTRACT }}$
We use a regression discontinuity design to examine students' responses to the negative incentive brought on by being placed on academic probation. Consistent with a model of introducing performance standards in which agents respond differently based on ability, we find that being placed on probation at the end of the first year discourages some students from returning to school while improving the performance of those who return. Contrary to the predictions of the model when ability is known, we find that heterogeneous discouragement effects result in high ability students having a greater overall dropout rate near the cutoff than lower ability students. The result can be explained by extending the model to allow for the performance standard to also affect self confidence (ability expectations). We also consider effects by gender and find that being placed on probation more than doubles the probability that men drop out but has no such discouragement effect for women.
\end{abstract}

Jason M. Lindo

Department of Economics

University of California, Davis

One Shields Avenue

Davis, CA 95616

jlindo@ucdavis.edu

Nicholas J. Sanders

Department of Economics

University of California, Davis

One Shields Avenue

Davis, CA 95616

njsanders@ucdavis.edu

\author{
Philip Oreopoulos \\ Department of Economics \\ University of British Columbia \\ Canada \\ and NBER \\ philip.oreopoulos@ubc.ca
}




\section{Introduction}

Academic probation is a nearly universal tool used by universities to ensure currently enrolled students achieve minimum academic standards. The general structure of such programs is simple -if a student's grade point average (GPA) is below a certain threshold, the student is placed on academic probation which serves as a wake-up call and can lead to escalating penalties. Our paper uses longitudinal data from three campuses at a large Canadian university to estimate the causal impact of being placed on academic probation by exploiting the discontinuous nature of the policy in a regression discontinuity (RD) design. More generally, our paper serves as an analysis of how individuals respond to a threat of punishment, as failure to improve one's grades after being placed on probation leads to suspension. Due to concerns about welfare, experiments providing such a large negative incentive are not often viable. Further, examining students' responses to academic probation provides a rare opportunity to examine the impacts of a negative incentive in an important real world setting.

Despite the prevalence of academic probation, the existing literature on its impact on students is limited to a single paper which compares the mean retention rate of engineering students on probation to the mean retention rate of those in good academic standing (Scalise, Besterfield-Sacre, Shuman, and Wolfe 2000). While there is a fairly extensive literature on the causal effects of other explicit university policies, these studies have focused primarily on positive incentives and services.$^{1}$ We offer the first study examining the causal effects of a negative incentive program.

Once a student has been placed on academic probation, she must earn a GPA above the

\footnotetext{
${ }^{1}$ Examples include papers analyzing the effects of advising and merit scholarships (Angrist, Lang, and Oreopoulos 2007; Leuven, Oosterbeek, and van der Klaauw 2006), tuition costs (Hakkinen and Uusitalo 2003; Heineck, Kifmann, and Lorenz 2006; Garibaldi, Giavazzi, Ichino, and Rettore 2007), financial aid (DesJardins, Ahlburg, and McCall 2002), and appointment to the Dean's List (Seaver and Quarton 1976; revisited by Cook and Campbell 1979).
} 
campus-set standard in the next term or she will be suspended from the university for one year. As such, placing students on academic probation is equivalent to setting a minimum standard for their future performance. In this sense, our results have implications for the wide variety of circumstances in which setting a standard might be used as a means of affecting performance. In addition to school administration, applications include management, parenting, and health and safety regulation.

Our results also provide an opportunity to empirically examine theoretical models of imposing performance standards. Bénabou and Tirole (2000) outline one such model that predicts that setting a performance standard involves an inherent tradeoff between motivating some agents to improve their performance and discouraging other agents from making any attempt at all. The model further predicts that a performance standard will be most discouraging for agents of relatively low ability who do not believe they can meet the standard. We explore the extent of this tradeoff by analyzing the effect of being placed on academic probation on students' decision to drop out and on the subsequent performance for those who remain, using students' high school grades as a measure of ability.

This paper also contributes to the growing literature on gender differences in response to educational incentives. Previous studies have found that women are more responsive to positive incentives than men: women respond to advising and scholarship programs while men do not (Angrist, Lang, and Oreopoulos 2007); tuition reductions impact college completion rates for women more than men (Dynarski 2005); and the effects of high school achievement awards appear limited to women (Angrist and Lavy 2002). However, because all of these papers focus on policies providing positive incentives, little is known about gender differences in response to negative incentives.

Our RD research design is motivated by the idea that students with a GPA just above the academic probation threshold after the first year provide a good counterfactual for those who have a GPA just below. As long as characteristics related to student outcomes are 
continuous through the threshold, we can measure the effect of being placed on probation in a RD design framework.

Our results indicate that the effects of academic probation are remarkably heterogeneous. Consistent with Bénabou and Tirole's model, being placed on academic probation after the first year discourages some students from returning to school and motivates those who remain to improve their subsequent performance. Contrary to the predictions of the model, we find that academic probation results in students of higher relative ability dropping out at a greater rate than students of lower relative ability. We discuss an extension of their model that can explain our results by allowing academic probation to have heterogeneous impacts on selfconfidence across ability. We also find that the impact on students' decisions to drop out of school differs by gender and native language. Being placed on academic probation doubles the probability that men drop out but has no such effect on women. Similarly, it discourages English speakers from returning but has no such effect non-native English speakers.

Finally, we consider the effects of being placed on academic probation on graduation rates. Because being placed on probation simultaneously motivates some students to improve their grades while causing others to drop out, there is no clear prediction of a positive or a negative effect on the probability of graduation. While we find insignificant effects overall, we find a strong negative effect for students of higher ability.

The rest of the paper is organized as follows. Section 2 describes the university and its academic probation program in more detail. Section 3 reviews Bénabou and Tirole's (2000) model of performance standards and considers an extension. Sections 4 and 5 describe the data and our empirical strategy. Section 6 presents our main results. Section 7 discusses our main results. Section 8 concludes. 


\section{Institutional Background}

Our data comes from a large Canadian university made up of three individual campusesone central campus and two smaller satellite campuses. The central campus (Campus 1) has an acceptance rate of about 55\% while the two satellite campuses (Campus 2 and Campus 3) have acceptance rates of approximately $77 \%$. The central campus resembles a large US state college while the satellite campuses have more part-time and commuter students. Campus 1 and Campus 2 share identical rules regarding academic probation - students with a cumulative GPA below 1.5 grade points are placed on academic probation. Campus 3 has a GPA cutoff at 1.6 grade points. For the purposes of our analysis, students from all three campuses have been combined into a single sample.2 We account for the difference in cutoff points in our RD analysis by using students' distance from their campus' cutoff as the running variable rather than absolute GPA.

When a student is placed on academic probation, a letter is sent notifying them of their current academic standing. The letter specifies why the student has been placed on probation, how to regain good academic standing, and the consequences of failing to improve. The letter also encourages students to continue at the university and improve their academic performance, and lists various services provided by the university aimed at helping them to do so. A copy of the letter is included in the appendix.

Because many freshman classes span the entire year, students' academic standing is not evaluated for the first time until the end of their first year ${ }^{3}$ At Campus 1 and Campus 2, students' academic standings are evaluated again at the end of every subsequent full

\footnotetext{
${ }^{2}$ In an earlier version of the paper, we used this across-campus variation to examine the effects of academic probation in a difference-in-difference framework. These results were similar to the RD estimates but imprecise due to a smaller sample size.

${ }^{3}$ Students also must attempt a minimum number of credits before they are evaluated. We omit all students who have not yet been evaluated by the end of their first full year. It is possible this is endogenous, though unlikely. If a student drops a course before the deadline, the course grade will not be counted in determining academic probation (or GPA in general). If this incentive to drop is continuous through the cutoff, however, this should not pose a problem.
} 
scholastic year and summer term. At Campus 3, students' academic standings are evaluated again at the end of each subsequent term.

Students on academic probation face the threat of suspension after subsequent sessions if their grades do not improve. At all campuses, students on probation can avoid suspension and return to good academic standing by bringing their cumulative GPA up to the cutoff. They can also avoid suspension after the next evaluation by achieving a per-session GPA above a particular minimum specified by their campus.4 Students who avoid suspension but fail to improve their cumulative GPA above the cutoff remain on academic probation and continue to face the threat of suspension until they regain good academic standing.

Students failing to sufficiently improve their grades are suspended for one full academic year. If suspended students choose to return to the university and again fail to sufficiently improve their grades, they can be suspended for three years. A third failure to meet the GPA requirement can lead to permanent suspension from all campuses.

\section{Theoretical Background}

In this section, we first review Bénabou and Tirole's (2000) model of agents' responses to a performance standard. The model is framed as a game between a principal and an agent, where the principal has the ability to set standards for the agent. While Bénabou and Tirole consider the model from the perspective of both the agent and the principal, we focus only on the agent. We then relate this model to academic probation and consider an extension.

Consider an agent facing a choice between three possible paths: option 1, option 2, or neither. If the agent chooses neither option, both her costs and benefits are 0 . If the agent attempts option $i$, she incurs $\operatorname{cost} c_{i}$ and, if successful, gains the benefit $V_{i}$. If the agent attempts option 1 or 2 and fails, she still incurs a cost but receives no benefit. Option 1 is

\footnotetext{
${ }^{4}$ At Campuses 1 and 2, the GPA cutoff is 1.7. At Campus 3, it is 1.6.
} 
an easy option with a low potential benefit while option 2 is a difficult option with a high potential benefit. Costs and benefits can be summarized as

$$
0<c_{1}<c_{2} \quad 0<V_{1}<V_{2}
$$

Ability is expressed as the probability of successfully completing either option, where higher ability translates into a higher probability of success. The probability of success for either option is $\theta$. Assuming that the agent is perfectly informed and knows $\theta$, she solves

$$
\max \left\{0, \theta V_{1}-c_{1}, \theta V_{2}-c_{2}\right\}
$$

Let $\underline{\theta}$ be the level of ability for which the agent is indifferent between attempting neither option and attempting option 1 and $\bar{\theta}$ be the level of ability for which the agent is indifferent between pursuing option 1 and pursuing option 2. With the following assumption,

$$
\underline{\theta} \equiv \frac{c_{1}}{V_{1}}<\bar{\theta} \equiv \frac{c_{2}-c_{1}}{V_{2}-V_{1}}<1
$$

which ensures that both options are optimal for at least some $\theta$, it can be shown that the lowest ability individuals $(\theta<\underline{\theta})$ choose neither option, the highest ability individuals $(\bar{\theta}<\theta)$ choose the difficult option, and the remaining individuals $(\underline{\theta}<\theta<\bar{\theta})$ choose the easier option. ${ }^{5}$

If the principal removes option 1 as a possible course of action, perhaps by forbidding it or imposing an additional cost on it such that it is always inferior to other options, then the

\footnotetext{
${ }^{5}$ Interestingly, the same results arise from a model in which the agent is sure to be successful in whichever task she chooses but the cost of each task is inversely related to the ability measure $\theta$. That is, the agent would solve $\max \left\{0, V_{1}-\frac{c_{1}}{\theta}, V_{2}-\frac{c_{2}}{\theta}\right\}$. Expressed in this way, the model can feature decreasing marginal returns to ability. Analogously, the same results can arise from a model in which the probability of success is increasing in ability and the cost is decreasing in ability. For example, if the agent solves $\max \left\{0, \sqrt{\theta} V_{1}-\frac{c_{1}}{\sqrt{\theta}}, \sqrt{\theta} V_{2}-\frac{c_{2}}{\sqrt{\theta}}\right\}$.
} 
agent will choose option 2 if and only if

$$
\theta \geq \frac{c_{2}}{V_{2}} \equiv \theta^{\star}
$$

and pursue neither option otherwise. Within the range of agents who would choose option 1 if it remained a possibility, the model predicts those with the higher ability will work harder (engaging in option 2) while those with the lower ability will give up (pursuing neither option) $[6$

This model naturally lends itself to analyzing how students might respond to being placed on academic probation. Consider the choice faced by two students (agents) whose first year GPAs were near the academic probation threshold, one just above and one just below. Since the student just above the threshold remains in "good academic standing," their options are unrestricted. These options can be placed into three categories: return to school with the intent of achieving some low GPA (option 1), return with the intent of achieving some high GPA (option 2), or dropping out of school (neither option 1 nor 2).

As a result of being placed on probation, the student just below the cutoff faces a different set of choices. We can think of academic probation as the administration forbidding, or placing an extremely large negative incentive on, pursuing option 1. In the framework of the model, if the student below the cutoff chooses to pursue option 1, she will be suspended from the university.

The testable implications of Bénabou and Tirole's theoretical framework are the following:

1. Low ability students should be more likely to drop out, whether option 1 is forbidden or not.

2. Forbidding option 1 will increase the overall probability of students dropping out and

\footnotetext{
${ }^{6}$ Specifically, those with $\theta$ in $\left[\theta^{\star}, \bar{\theta}\right]$ will now choose option 2 while those with $\theta$ in $\left[\underline{\theta}, \theta^{\star}\right]$ will now choose not to pursue either option.
} 
increase the performance of those who return.

3. Forbidding option 1 will cause relatively low ability students to drop out and relatively high ability students to return and work harder.

\section{Data}

The data used in the analysis is from a administrative data set of college students from the large Canadian university described in Section 2. Observations are at the student level and cover a ten-year period from 1995 to 2005 with each scholastic year broken into Fall, Winter, and Summer terms. The data includes student term registration status, GPA, gender, age, first language, and a measure of high school performance. We use the set of background variables for falsification tests and as controls in some regression specifications.

We restrict the sample to students we can potentially observe for two years. Since the data spans through the end of the 2005 school year, we restrict to students who entered in the 2004 school year or earlier. This leaves nine cohorts of students. We omit students with missing data for any variables of interest. 7 We also restrict the sample to students entering the university between the ages of seventeen and twenty-one (99\% of the remaining sample). Additionally, we keep only students who have had their academic standing evaluated at the end of their first year (98\% of the remaining sample).$^{8}$ Finally, we limit the sample to students those within a bandwidth of 1.4 grade points of their academic probation cutoff. This effectively drops students who failed all of their first year classes in addition to students who cleared the cutoff by a wide margin 9 The resulting sample includes 32,697 students.

\footnotetext{
${ }^{7}$ The largest impact this has on the sample is due to omitting students with missing high school grade information which reduces the sample by $16 \%$. The primary reason high school grades are missing for students is that they attended high school outside the province.

${ }^{8}$ In almost all cases, a student is not evaluated due to an insufficient number of attempted credits.

${ }^{9}$ As a robustness check, some regressions have further bandwidth restrictions. This is discussed in the following section.
} 
The first column of Table 1 shows the descriptive statistics for the sample. The students average entry age is 18.7 years. Approximately $38 \%$ are male, $73 \%$ have English as their first language, and $88 \%$ were born in North America. $53 \%$ of the students attend Campus 1 (the central campus) ${ }^{10}$ Of the remaining students, $20 \%$ attend Campus 2 and $27 \%$ attend Campus 3. For the most part the means at the limits of the cutoff are most relevant and these are discussed in subsequent sections. Before proceeding, we should note that a sizable fraction of students $(23 \%)$ are placed on academic probation after their first year. While it is unfortunate that so many students fail to meet their campus' academic requirements, this is a positive aspect for our research design because it improves our ability to obtain estimates on both sides of the probationary cutoff.

\section{Empirical Strategy}

We begin by estimating the impacts of being placed on academic probation after the first year. At the end of the first year the probation status for student $i$ at campus $c$ is a deterministic function of their GPA, which can be expressed as

$$
P R O B_{i c}^{\text {year } 1}=1\left(G P A_{i c}^{\text {year } 1}<G P A C U T_{c}\right)
$$

where $G P A_{i c}^{\text {year } 1}$ is student $i$ 's cumulative GPA at the end of the first year and GPACUT is the probationary cutoff at the student's campus. Because the discontinuity in probation status is "sharp," as we will show in Section 6.1, as long as other student characteristics related to the outcomes are continuous through the threshold, the treatment effect for students near the threshold can be obtained by comparing the outcomes of students just below the threshold to those just above.

\footnotetext{
${ }^{10}$ If a student's first language is not English, it is usually an Asian language. Despite being a Canadian institution, less than one percent of students have French as their first language.
} 
The following equation can be used to estimate the impact of being placed on academic probation after the first year on student outcomes:

$$
Y_{i c}=m\left(G P A_{i c}^{\text {year } 1}\right)+\delta 1\left(G P A_{i c}^{\text {year } 1}<G P A C U T_{c}\right)+u_{i c},
$$

where $Y_{i c}$ is an outcome for student $i$ at campus $c, m\left(G P A_{i c}^{\text {year } 1}\right)$ is a continuous function of students' standardized first year GPAs (the distance from their campus' probationary cutoffs), $1\left(G P A_{i c}^{\text {year } 1}<G P A C U T_{c}\right)$ is an indicator equal to one if the student's GPA is below the probationary cutoff, and $u_{i c}$ is a random error term. The coefficient of interest is $\delta$, the estimated impact of being placed on academic probation after the first year. Since GPA data are in hundredths of a grade point, we face a running variable with a discrete support. Following Lee and Card (2008), we estimate the previous equation by assuming a low-order polynomial functional form for $m()$ and cluster our standard errors on students' normalized first year GPAs. Specifically, $m()$ is a second order polynomial that is flexible on each side of the cutoff 11 As a robustness check we also estimate the effects controlling for observables.

As noted by Imbens and Lemieux (2008), the main concern with such an approach is that the results may be sensitive to outcome values for observations far away from the cutoff. For this reason, our main estimates use only data within a bandwidth of 1.4 from the cutoff, dropping individuals who fail all (or nearly all) of their first year classes and those who

\footnotetext{
${ }^{11}$ Our regression equation is given by:

$$
\begin{aligned}
& +\gamma_{1}\left(G P A N O R M_{i c}^{\text {year } 1}\right) \times 1\left(G P A_{i c}^{\text {year } 1}<G P A C U T_{c}\right) \\
& +\gamma_{2}\left(G P A N O R M_{i c}^{\text {year } 1}\right)^{2} \times 1\left(G P A_{i c}^{\text {year } 1}<G P A C U T_{c}\right) \\
& +u_{i c}
\end{aligned}
$$$$
Y_{i c}=\alpha+\delta_{l e} 1\left(G P A_{i c}^{\text {year } 1}<G P A C U T_{c}\right)+\beta\left(G P A N O R M_{i c}^{\text {year } 1}\right)
$$

where $\delta_{l e}$ is the estimated impact of being placed on academic probation after the first year. Our figures suggest this functional form is a good fit. In prior versions of this paper, we found similar results using higher order polynomials.
} 
cleared the cutoff by more than 1.4 grade points. We also show estimates using bandwidths of 1.0 and 0.6 to verify that our results are not sensitive to choice of bandwidth. While we present results using rectangular kernel weights, we have also verified that the results are robust to performing local linear regression with triangular kernel weights.

We use the strategy described thus far to estimate the impacts of being placed on academic probation after the first year. However, we are also interested in analyzing the impacts of ever being placed on academic probation. The approach described above does not produce such an estimate because "control" students just above the cutoff after their first year may be placed on probation after later evaluations. As a result, we must use a slightly different approach.

To estimate the impact of ever being placed on academic probation, we rely on the fact that students' first year GPAs create a discontinuity in whether or not a student is ever placed on academic probation (as shown in Section 6.1). Since this discontinuity is fuzzy (the change in the probability of treatment is less than one), the impact on student outcomes can be obtained by adjusting estimated discontinuities in outcomes by the estimated discontinuity in treatment status. This is equivalent to a two-stage least squares estimate in which the variation in treatment status is driven by the discrete change occurring at the threshold (Hahn, Todd, and Van der Klaauw 2001). We obtain estimates and their standard errors based on two-stage least squares regression in which the excluded instrument is $1\left(G P A_{i c}^{\text {year } 1}<G P A C U T_{c}\right) \cdot{ }^{12}$

\section{Results}

In this section, we begin by testing the validity of the regression discontinuity design. We then examine the effects of being placed on academic probation on students' decisions to drop out,

\footnotetext{
${ }^{12}$ These estimates take the same approach to bandwidth choice, kernel weights, and standard errors as the other estimates.
} 
subsequent GPAs, probabilities of suspension, and graduation rates and the heterogeneity of these effects across student ability, gender, and native language.

\subsection{Tests of the Validity of the RD Approach}

Non-random sorting across the cutoff is a main concern with any RD design in which the threshold could be known to those who might be affected by the policy. In our case, this would appear if students just below the cutoff were actively influencing their GPAs to avoid probation (e.g. convincing teachers to give them a higher grade to raise their GPA above the cutoff point) or expending just enough effort to get grades above the cutoff. By focusing on academic probation status at the end of first year, we decrease the likelihood of this concern. First year students are less familiar with campus policies and, thus, less likely to know what grades would be required to avoid academic probation. In addition, though Campus 3 has semester-length first year courses, at Campuses 1 and 2 most first year courses span the entire year and the majority of the grade is based on evaluation at the end of the term, making it difficult for students to correctly "hit" a performance point just above the cutoff, especially given that their overall GPA is calculated over several courses.

If sorting were a problem, we would expect to see a discontinuity in the distribution of grades at the cutoff, as a disproportionate number of students would fall just above the cutoff relative to the number of students just below the cutoff ${ }^{13}$ Figure 1 shows the distribution of students' first year grades relative to their campus cutoffs, with cell sizes of 0.05 grade points. Using each of these cells as an observation, the figure also shows the predicted cell sizes based on local linear regressions using triangular kernel weights and a bandwidth of 0.6. The estimated discontinuity at the threshold is not statistically significant, indicating

\footnotetext{
${ }^{13}$ At the same time, this might not be the case if the distribution of grades is fixed. For example, there might be a situation in which some students manipulate their grades to get themselves above the cutoff but, as a result of their efforts, other marginal students are pushed below the cutoff.
} 
that the distribution of students is continuous through the threshold 14

Our research design requires both observable and unobservable characteristics related to student outcomes to be continuous through the threshold. Table 2 and Figure 2 explore the extent to which a wide range of observable characteristics are continuous through the cutoff. Significant discontinuities would indicate that students with particular characteristics are more or less able to manipulate their grades so as to avoid being placed on probation. As a whole, these estimates support the validity of our research design. We find no significant discontinuities in students' high school grades, credits attempted in the first year at the university, age at entry, gender, birthplace, or campus attended. The only variable for which there is some evidence of a discontinuity is whether or not English is a student's first language and the estimate is only statistically significant in some specifications. ${ }^{16}$

The graphs in Figure 2 are also useful because the slopes of the curves inform us about the relationship between students' characteristics and their performances in their first year of college. Most relevant to the results that follow, the strong positive relationship between high school grades and college grades indicates that high school grades are a good predictor of a student's success in college. Within our sample, a one-percentile increase in the high school grade measure is associated with a 0.1 increase in first year GPA. This motivates our use of the label "high ability" in reference to students with high school grades above the sample median and "low ability" for those with grades below the sample median 17 In Section 7, we will return to this issue and further consider whether high school grades are a good measure of ability conditional on students' first year grades at the university.

\footnotetext{
${ }^{14}$ We have also tested for discontinuities in the distribution using cell sizes of $0.01,0.02$, and 0.04 , grade points and with varying bandwidths. These results were never statistically significant.

${ }^{15}$ This test is similar to that proposed by McCrary (2008).

${ }^{16}$ As in Figure 1, we have also verified that there are not significant discontinuities in the distributions of students for whom English is their first language and students for whom it is not. Similarly, we do not find significant discontinuities in the distributions of students for any of the other subgroups we consider in our analysis.

${ }^{17}$ Note that the sample of low ability students near the academic probation threshold will be greater than the sample of high ability students near the threshold since the median is based on all entering students.
} 


\subsection{First Year GPAs and Academic Probation}

Figure 3 and the first panel of Table 3 show the estimated discontinuity in probation status at the end of the first year. Because the discontinuity is sharp, discontinuities in other student outcomes can be interpreted as the causal effect of being placed on probation at the end of the first year. Such estimates are equivalent to the following thought experiment: what if students' academic standings were not evaluated after the first year and, instead, were first evaluated after the completion of their next term?

In looking at the effects on long-term measures of achievement, we are also interested in the effect of ever being placed on academic probation. This question is distinct from the former because students just above the cutoff after their first year are placed on probation if their cumulative GPA falls below the cutoff in the future. As shown in Figure 4 and the second panel of Table 3, 25 to 30\% of those just above the cutoff at the end of their first year are placed on probation at some point in their academic careers. This implies that a substantial fuzzy discontinuity exists and we can estimate the impact of ever being placed on probation on long-run measures of student achievement using standard techniques associated with fuzzy regression discontinuity designs (as discussed in Section 5).

\subsection{The Immediate Response to Academic Probation}

The immediate question that all students face at the end of their first year is whether or not to continue at the university 18 Students who have been placed on academic probation have been informed that they will be suspended if their GPA does not meet the campus-set standard in their next term. However, at this point in time, continued enrollment is not impeded in any other way.

Table 4 and Figure 5 show the estimated impact on students' decisions to permanently

\footnotetext{
${ }^{18}$ Manski (1989) and Altonji (1993) develop extensive models that explore the sequential nature of the schooling decision under uncertainty.
} 
leave the university after their first year. The estimates, which are statistically significant at the one percent level in all specifications, indicate that being placed on academic probation at the end of the first year increases the probability that a student leaves the university by 2.2 to 2.7 percentage points, or by more than $50 \%$ of the control mean. ${ }^{19}$

Table 5 and Figure 6 explore the extent to which different subgroups of students respond to being placed on probation after the first year in different ways 20 These results suggest that the average effects shown in Table 4 and Figure 5 mask substantial heterogeneity.

The estimated impact on the "low ability" group (those with high school grades below the median of students entering the university), significant at the ten percent level in all specifications, suggests that being placed on probation increases the probability of dropping out by 1.6 percentage points, or approximately a third. We find a much greater effect on students of higher ability (high school grades above the median of students entering the university), for whom being placed on academic probation doubles the probability of dropping out. In fact, the impact of academic probation is so great for high ability students near the cutoff that they are more likely to drop out than their lower ability counterparts. This is not the case for students just above the cutoff.

We also find heterogeneous effects across gender and native language. Our estimates indicate that being placed on academic probation more than doubles the probability that men drop out after the first year but has no effect on women's decision to continue at the university. ${ }^{21}$ It is unlikely that this finding reflects a general unresponsive nature of females at the university we study - a prior study at the same university found that women were

\footnotetext{
${ }^{19}$ It should be noted that the control mean is not the overall drop-out rate but, rather, the drop-out rate for students just above the cutoff.

${ }^{20}$ The table is limited to estimates using a bandwidth of 1.4 -in general, the estimates are not sensitive to the choice of bandwidth.

${ }^{21}$ The estimated impacts on subgroups defined by the interaction between ability and gender indicate that the prior results by ability are mostly driven by males. The estimated impacts on both high and low ability females are insignificant. Being placed on probation approximately doubles the probability that low ability men drop out and triples the probability that high ability men drop out.
} 
more responsive to experimentally offered peer advising and organized study group services (Angrist, Lang, and Oreopoulos 2007). In results not shown, we find this gender difference does not appear to be driven by differences in the types of courses that men and women attempt in their first year ${ }^{22}$ The results that follow indicate that it is not that women do not respond to being placed on probation but that they respond differently. Lastly, we find that probation increases the probability of dropping out for native English speakers but that there is no impact on non-native English speakers.

\subsection{The Impact on Subsequent GPA}

Students on academic probation who choose to remain at the university have a substantial incentive to improve their grades to the campus-set standard - failing to do so results in being suspended from the university for a year. The first panel of Table 6 and Figure 7 show the impact of being placed on academic probation on students' subsequent GPAs. Specifically, the outcome variable is a student's GPA in the next session in which they are evaluated. ${ }^{23}$ The estimates suggest that being placed on academic probation causes students to improve their GPAs by approximately 0.2 grade points, a $66 \%$ greater improvement than students who just surpass the probationary cutoff.

It is important to note that these estimates might be biased by the effect of academic probation on the composition of students who continue to enroll in the university. For

\footnotetext{
${ }^{22}$ Specifically, we have separately considered the impact for students who took first year courses that disproportionately enrolled men and for students who took first year courses that disproportionately enrolled women. Regardless of the gender composition of the peers in their first year courses, we find no evidence that being placed on academic probation impacts the decision to drop out for women and we do find evidence that it impacts men. We have also analyzed the impact for students who took at least half of their first year credits in science courses versus those who did not; similar gender differences also appear in these results.

${ }^{23}$ Note that the "next session" will be a summer session if students are enrolled in summer classes and a second year session if they are not. If we were to use only second year GPAs, there would be missing data for students placed on academic probation after their first year who do poorly in summer school and are suspended for their second year. While summer school grades tend to be higher than grades during the rest of the year, in results not shown but available upon request, we find no statistically significant impact of academic probation on the probability that a student takes summer courses.
} 
example, if academic probation results in the attrition of relatively low ability students, then we would expect the estimated impact on GPAs to be positive even if being placed on probation has no effect on individual behavior beyond the choice to drop out. However, in the previous section we showed that it is actually the higher ability students who are most discouraged from returning to the university which suggests that our estimates represent a lower bound of the true effect on GPAs. As an additional check, the second and third panels of 6 show that the impact on GPAs remains positive and significant under very conservative assumptions about what GPAs would have been observed for students who did not return for another session after being placed on probation ${ }^{24}$

Table 7 and Figure 8 show the estimated impacts on students' subsequent GPAs separately for low ability students, high ability students, men, women, native English speakers, and non-native English speakers. All of the estimates suggest that being placed on academic probation after the first year improves students' subsequent GPAs ${ }^{25}$ Since we found no effect on the continued enrollment of women and non-native English speakers, the estimated impact of academic probation on subsequent GPAs is unlikely to be driven by composition bias for these groups. Thus, at least for these groups of students, we can be relatively confident that the impact on students' GPAs is truly positive.

\subsection{The Impacts on Suspension and Graduation}

The previous sections analyzed the impact of being placed on academic probation after the first year on students' outcomes immediately following their first evaluation. When those outcomes are measured, students are either currently on probation or in good standing. In

\footnotetext{
${ }^{24}$ Using the same RD approach, we have also looked at the difficulty of the classes that returning students take using average course grades as a proxy. There is no evidence that being placed on probation causes students to take courses in which grades tend to be higher.

${ }^{25}$ We cannot rule out that the effects are the same across groups. Even if the estimates were substantially different for a particular group, we would not be able to ascertain the extent to which the difference was due to composition bias.
} 
this section, in which we consider long-run effects, we will continue to estimate the impact of being placed on academic probation after the first year. Since these outcomes are measured at a later date, some students who were in good standing after their first year have been placed on academic probation in subsequent evaluations. We exploit the fuzzy discontinuity in whether or not students are ever placed on academic probation to estimate the impact of ever being placed on probation.

Table 8 and Figure 9 show the estimated impacts on ever being suspended. Not surprisingly, being placed on probation substantially increases the probability of ever being suspended. One important thing to note is that the control means are not zero-some of the students who just avoided academic probation after their first year are placed on probation after later terms, fail to improve their grades, and are subsequently suspended.

Table 9 and Figure 10 show the estimated impacts on ever being suspended by subgroups. These results indicate that academic probation increases the probability of suspension for all of the subgroups considered but that the magnitude of the effect varies across groups. We find that the effect on suspension is greater for high ability students than low ability students. Previous results suggested that probation increases the probability that high ability students drop out but has no effect on the continued enrollment of the low ability students. As such, this result cannot be attributed to relatively fewer high ability students who are at risk of suspension after returning to school. This finding is consistent, however, with our previous estimates suggesting that probation has a greater positive impact on the grades of low ability students.

We also find that the estimated effect of being placed on probation is larger for women than men, but this may be a result of the differences in academic probation's effect on drop out rates documented in Section 6.3. Specifically, since probation increases the probability that men leave the university before registering for any future terms, there are relatively fewer men at risk of being suspended in future terms. 
Lastly, we find that academic probation has a greater impact on the probability of suspension for students whose first language is not English. Like the results by gender, this finding might be partially explained by the differences in academic probation's impact on students' decisions to return to the university that were documented in Section 6.3 .

While it is relatively simple to analyze the impact of academic probation on the probability of graduation, it is difficult to unpack the various mechanisms that are set into motion by the treatment. The estimates in Section 6.3 demonstrated that a sizable share of students around the threshold drop out from the university as a result of being placed on probation. If this were the only effect, then we would expect academic probation to either reduce the probability of graduating or to have no effect if the only students who drop out are those who would not have graduated regardless. However, if academic probation motivates the remaining students to improve their grades, as our estimates suggest in Section 6.4, then academic probation might increase the probability of graduating. Finally, academic probation might reduce the probability of graduation because it increases the probability of suspension, which in turn likely increases the probability that a student drops out before finishing their degree.

Figure 11 and Table 10 show the estimated impacts of academic probation on whether or not a student has graduated within four, five, or six years of their initial enrollment. For these estimates, our sample is restricted to students in cohorts who are observed for at least four, five, or six years, respectively, whether they graduate or not. While the point estimates are consistently negative, we cannot reject that being placed on academic probation has no effect on the probability of graduation on average. In addition, relatively large standard error estimates imply that we cannot rule out sizable effects in either direction.

Figure 12 and Table 11 show the estimated impacts on graduation rates for a variety of subgroups. In most cases, we cannot rule out that the impacts are the same across groups. However, the estimated impact on the probability of graduating within five or six years is especially large for students with high school grades above the median. For these students, 
ever being placed on academic probation reduces the probability of graduation within five years by 14 percentage points and reduces the probability of graduation within six years by 20 percentage points ${ }^{26}$ While these magnitudes are very large, they are less surprising given that we found these students are especially discouraged from continuing their enrollment immediately after being placed on probation and that we found only weak evidence that being placed on probation has a positive impact on the GPAs of those who return.

\section{Discussion}

As a whole, the most striking feature of our results is the heterogeneity in students' responses to academic probation. Consistent with Bénabou and Tirole's (2000) theoretical model of performance standards, we do find that some students are discouraged from putting forth any effort to meet the standard (choosing to drop out) while those who return are motivated to improve their GPAs. Bénabou and Tirole's model also predicts that the individuals with the lower relative ability should be the most likely to give up. This is fairly intuitive since these individuals are least likely to be able to meet the standard. However, we find that the performance standard imposed by academic probation leads to higher ability students having the larger drop out rate.

This unexpected result raises the question: are high school grades a good measure of ability for students near the cutoff? Given that all of the students entered the same university and that students near the cutoff earned approximately the same first year GPA, some concern about this labeling may be warranted. For example, the students with relatively low high school grades may have been admitted to the university based on other characteristics that signal high ability to admissions officers that we cannot observe. These signals might

\footnotetext{
${ }^{26}$ Like the estimated impact on the probability of dropping out at the end of the first year, these estimates are driven primarily by males. For high ability males, ever being placed on academic probation at the end of the first year reduces the probability of graduating within six years by more than a third.
} 
include the difficulty of a student's high school, the number of advanced placement classes taken, or involvement in extracurricular activities.

To answer this question, we can compare the subsequent performance of students in our "high ability" group and "low ability" who barely avoided being placed on academic probation at the end of their first year. ${ }^{27}$ The control means from Tables 5, 7, 9, and 11. indicate that, even though they earned the same first year GPA as the students we label "low ability," the students we label "high ability" are less likely to leave the university at the end of their first year, earn higher GPAs in their next term, are less likely to ever be suspended, and are more likely to graduate within four, five, and six years. As a whole, these results suggest that our measure of ability effectively predicts academic performance for students at the university, even conditional on first year GPA.

Given that we are confident about our measure of ability, we suspect that Bénabou and Tirole's model does not predict the results that we observe across ability because the assumption of perfect information does not hold in this setting ${ }^{28}$ That is, students may not know their true ability (or their probability of meeting the performance standard). We can reconcile the model with our findings if we extend it to allow agents to act according to self-perceived ability, where self-perceived ability can be affected by being subjected to a performance standard.

In a situation in which students do not have perfect information and act according to self-perceived ability, being placed on academic probation can be thought of as a negative signal sent by the administration to the student. Thus, being placed on academic probation not only reduces a student's second year choice set but also negatively affects her perceived ability.29

\footnotetext{
${ }^{27}$ We focus on control students to avoid confounding differences in performance due to ability with differences due to heterogeneous treatment effects.

${ }^{28}$ Falk, Huffman, and Sunde (2006) find that individuals are substantially uncertain about their abilities in an experimental setting.

${ }^{29}$ This feature is similar to models of performance rewards offered by principals and their impacts on the
} 
In this framework, an imperfectly informed student acts according to her self-perceived ability, $\tilde{\theta}$, which is a function of her true ability, $\theta$, and whether or not she has been placed on academic probation. Here, an unrestricted student solves

$$
\max \left\{0, \tilde{\theta}(\theta, A P) V_{1}-c_{1}, \tilde{\theta}(\theta, A P) V_{2}-c_{2}\right\}
$$

Analogous to the previous version of the model, students with the lowest self-perceived abilities will choose to drop out, students with the highest self-perceived abilities will pursue option 2, and the remainder will pursue option 1 if it is allowed. However, it is not necessarily the case that those with the highest self-perceived ability have the highest true ability. While we would generally expect a positive relationship between self-confidence and true ability, subjecting agents to a performance standard might alter this relationship.

Consider two students: Hiabil and Loabil. Hiabil earned straight A's and was a top student throughout high school. Due to an uncharacteristically bad first year at the university, Hiabil performs worse than she expected and is placed on academic probation. Loabil, having consistently earned a $\mathrm{B}+$ average throughout high school, believes she is a mediocre student. Lobail performs below her expected level as well and is also placed on academic probation. 30

As a negative signal sent by the administration, we would expect being placed on academic probation to reduce the self-confidence of both students. However, the impact of the signal may vary due to their prior experiences. Since Hiabil is accustomed to success, being placed on academic probation may come as a great shock and reduce her self-confidence by a self-confidence of agents discussed in Bénabou and Tirole (2003). In a related study, Eriksson, Poulsen, and Villeval (2008) find that agents rarely quit the provided task regardless of differences in performance feedback. However, the decision to quit in their experiment is quite different from the decision faced by the students in our analysis. Whereas dropping out of school has important long-term implications, the primary incentive for individuals to quit the experimental task was the chance to use the remaining time available to read a newspaper (or materials they brought with them).

${ }^{30}$ Due to the random element involved in first year GPAs, students may have a wide range of abilities despite their similar first year performance. 
large amount. However, it might have a smaller impact on Loabil's self-confidence since, due to her prior levels of scholastic success, she expected to experience difficulty. If the difference in the impacts is great enough, Hiabil could have a lower post-signal self-confidence than Loabil even though she has higher ability. In this manner, a performance standard that affects students' perceived abilities heterogeneously could change the relative ordering of $\tilde{\theta}$ such that $\tilde{\theta}_{h}<\tilde{\theta}_{l}$ even though $\theta_{h}>\theta_{l}$. As a result, high ability individuals could be more likely to give up than individuals of lower ability ${ }^{31}{ }^{32}$

In this extended model, the decision to return to school can serve as a measure of revealed self-confidence $(\tilde{\theta})$, allowing us to further consider the impacts of being subjected to the performance standard of academic probation. Our data has clear analogues to each of the three main variables considered: agents who are subjected to the performance standard (academic probation) and similar agents who are not, a measure of agents' abilities $(\theta$, high school grade percentile ranking), and self-confidence ( $\tilde{\theta}$, the decision to return to school). A more vivid picture of the relationship between these variables can be obtained by adding the measure of ability as well its interaction with being placed on academic probation to our previous regression equations.

Using these estimates, Figure 13 demonstrates the relationship between self-confidence and ability for students on academic probation and those in good standing. Note that the curves are intended to demonstrate the relationship between ability and self-confidence within

\footnotetext{
${ }^{31}$ Similarly, our findings can also be reconciled using a two-skill model. Consider students with two types of skill important for high school and college, $S_{h s}$ and $S_{c}$, respectively, which are positively correlated. Students understand that the skills for high school and college are not one in the same. Thus, once students are informed whether or not they are placed on probation, they evaluate their $S_{c}$ based on their $S_{h s}$ in addition to the new information. The signal provided by academic probation, of course, is negative. If the magnitude of the "shock" is increasing in $S_{h s}$, the model would be consistent with the top high school students being most likely to drop out even though, on average, they have a greater aptitude for college.

${ }^{32}$ It is also possible that the differences we observe could be driven by differential returns to education by ability, as documented by Altonji and Dunn (1996) and Ashenfelter and Rouse (1998). For this to explain the behavior that we observe, the return to education would have to be higher for high ability students in good standing than low ability students in good standing, while the opposite would have to be true for those on academic probation.
} 
each group, but not across groups (since we would expect a lower probability of returning for those on probation even if their self-confidence was unchanged). Within the framework of the model, students on a given curve are directly comparable since they face the same set of choices. The slopes of the curves indicate the following:

1. For students who are not subjected to the performance standard, there is little relationship between ability and self-confidence.

2. Being subjected to the performance standard causes agents of higher ability to have lower self-confidence than those of lower ability.

The lack of a relationship between revealed self-confidence and ability for students in good academic standing is consistent with the psychology literature on estimated intelligence, which tends to find only a weak positive relationship 33 The negative relationship between revealed self-confidence and ability for those on academic probation diverges from previous findings. However, as described above, it is consistent with a model in which high ability agents respond more negatively to being subjected to a performance standard. This result may also differ from previous studies because we focus on a measure of revealed selfconfidence rather than a traditional survey in which participants suffer little or no penalty from misrepresenting their true beliefs about their ability. More research along these lines is needed.

The two enumerated findings both raise the question: which students more accurately assess their own ability - those of high or low ability? We cannot answer this question directly since we do not know the dropout rates that we would observe if students had perfect information. In an experimental study of students at the University of British Columbia, Heine, Takata, and Lehman (2000) found that, even when confronted with information implying that their performance was below average, students still thought they could outperform most

\footnotetext{
${ }^{33}$ See Furnham (2001) for a review of the literature.
} 
of their classmates. Following this finding, if we assume that all students are overconfident, then these findings would imply that low ability students are especially overconfident.

Though these models have no testable predictions regarding gender, the heterogeneity in changes to perceived self-confidence discussed above may be relevant for the gender differences we find as well. Under the interpretation that the decision to continue at the university is determined by self-perceived ability, our findings suggest that men have higher self-perceived ability than women in the absence of probation and lower self-perceived ability after being placed on probation. As with the differences across abilities, this suggests that men may have a stronger negative reaction to being placed on probation because their self confidence is greater to begin with.

Our findings might also be related to gender differences in overconfidence. Studies have repeatedly shown that men are more likely to overestimate their scholastic abilities while women are more accurate in their assessments 34 If being placed on academic probation causes students to more accurately assess their own abilities, which is plausible given the high stakes that are involved, then the gender difference would be expected since men would be required to make a greater adjustment.

\section{Conclusion}

We show that being placed on academic probation significantly discourages students from returning to school after their first year of university study. Surprisingly, it is the highest ability individuals who are discouraged most. The effect on students with high school grades above the median of entering students is so large that, as a group, they are less likely to return than students of lower ability. We discuss how this finding can be reconciled with the

\footnotetext{
${ }^{34}$ See Lundeberg, Fox, and Punćochaŕ (1994), Pajeres (1996), Beyer (1999), Furnham (2001), and Chevalier, Gibbons, Thorpe, and Hoskins (2007). Male overconfidence has also been documented in non-scholastic environments such as finance (Barber and Odean 2001).
} 
theory of performance standards.

Consistent with a sizable literature on students' responses to positive incentives, we show that there are also gender differences in response to a negative incentive. We find that academic probation doubles the probability that men drop out but has no such effect on women. We also find evidence that being placed on probation improves the grades for individuals of both genders.

Ideally, a performance standard might just "weed out" those who have no chance at success and serve as a motivation for the others. In our setting, it would be a tool that improves graduation rates. While we do find positive effects on the subsequent GPAs for students who continue to enroll, we find no evidence that being placed on academic probation improves graduation rates. In fact, we find a very large negative impact on high ability students near the cutoff - ever being placed on probation reduces their probability of graduation by 20 percentage points. Like the effects on the probability of dropping out, this effect is so large that these students are less likely to graduate than students of lower ability.

Our results have important consequences for the wide variety of circumstances in which standards might be applied as a means of improving performance. Our findings on gender suggest that, as with positive incentives, negative incentives are more likely to yield the desired result with women than with men. Considering the current concerns regarding gender differences in academic success in both early and advanced education, this raises an important question - can incentive schemes be designed that "work" for men?

We also confirm that a performance standard can entail a tradeoff between causing some to work harder and causing others to give up. While this outcome might be anticipated by many potential standard setters, our results suggest an additional consideration that is more unexpected. Specifically, since high ability individuals are disproportionately likely to react by giving up, a standard-setter can be left with individuals of lower ability, offsetting the improved performance of those who remain. 


\section{References}

Altonji, Joseph G., "The Demand for and Return to Education When Education Outcomes are Uncertain," Journal of Labor Economics, 1993, 11 (1), 48-83.

- and Thomas A. Dunn, "The Effects of Family Characteristics on the Return to Education," The Review of Economics and Statistics, 1996, 78 (4), 692-704.

Angrist, Joshua D. and Victor Lavy, "The Effect of High School Matriculation Awards: Evidence from Randomized Trials," 2002. NBER Working Paper No. 9389.

Angrist, Joshua, Daniel Lang, and Philip Oreopoulos, "Incentives and Services for College Achievement: Evidence from a Randomized Trial," 2007. NBER Working Paper No. 12790 .

Ashenfelter, Orley and Cecilia Rouse, "Income, Schooling, and Ability: Evidence from a New Sample of Identical Twins," The Quarterly Journal of Economics, 1998, 113 (1), $253-284$.

Barber, Brad M. and Terrance Odean, "Boys Will be Boys: Gender, Overconfidence, and Common Stock Investment," Quarterly Journal of Economics, 2001, 116 (1), 261-292.

Bénabou, Roland and Jean Tirole, "Self-Confidence and Social Interactions," 2002. NBER Working Paper No. 7585.

_ and _ , "Intrinsic and Extrinsic Motivation," The Review of Economic Studies, 2003, 70 (3), 489-520.

Chevalier, Arnaud, Steve Gibbons, Andy Thorpe, and Sherria Hoskins, "Students Academic Self Perception," 2007. UCD Geary Institute Discussion Paper Series.

Cook, Thomas D. and Donald T. Campbell, Quasi-experimentation: Design E Analysis Issues for Field Settings, Houghton Mifflin Company, 1979.

DesJardins, Stephen L., Dennis A. Ahlburg, and Brian P. McCall, "Simulating the Longitudinal Effects of Changes in Financial Aid on Student Departure from College," The Journal of Human Resources, 2002, 37 (3), 653-679.

Dynarski, Susan, "Building the Stock of College-Educated Labor," 2005. NBER Working Paper No. 11604.

Eriksson, Tor, Anders Poulsen, and Marie-Claire Villeval, "Feedback and Incentives: Experimental Evidence," 2008. IZA Discussion Paper No. 3440.

Furnham, A., "Self-estimates of intelligence: culture and gender difference in self and other estimates of both general (g) and multiple intelligences," Personality and Individual Differences, 2001, 31 (8), 1381-1405. 
Garibaldi, Pietro, Francesco Giavazzi, Andrea Ichino, and Enrico Rettore, "College Cost and Time to Complete a Degree: Evidence from Tuition Discontinuities," 2007. NBER Working Paper No. 12863.

Hahn, Jinyong, Petra Todd, and Wilbert Van der Klaauw, "Identification and Estimation of Treatment Effects with a Regression-Discontinuity Design," Econometrica, 2001, 69 (1), 201-209.

Häkkinen, Iida and Roope Uusitalo, "The effect of a student aid reform on graduation: a duration analysis," 2003. Mimeo.

Heine, Steven J., Toshitake Takata, and Darrin R. Lehman, "Beyond SelfPresentation: Evidence for Self-Criticism Among Japanese," Personality and Social Psychology Bulletin, 2000, 26 (1), 71-78.

Heineck, Martin, Mathias Kifmann, and Norman Lorenz, "A duration analysis of the effects of tuition fees for long term students in Germany," 2006. Mimeo.

Imbens, Guido W. and Thomas Lemieux, "Regression discontinuity designs: A guide to practice," Journal of Econometrics, 2008, 142 (2), 615-635.

Lee, David S. and David Card, "Regression discontinuity inference with specification error," Journal of Econometrics, 2008, 127 (2), 655-674.

Leuven, E., H. Oosterbeek, and V. van der Klaauw, "The Effect of Financial Rewards on Students' Achievement: Evidence from a Randomized Experiment," 2003. CEPR Discussion Paper no. 3921.

Lundeberg, Mary A., Paul W. Fox, and Judith Punćochaŕ, "Highly Confident, but Wrong: Gender Differences and Similarities in Confidence Judgments.," Journal of Educational Psychology, 1994, 86 (1), 114-121.

Manski, Charles F., "Schooling as experimentation: a reappraisal of the postsecondary dropout phenomenon," Economics of Education Review, 1989, 8 (4), 305-312.

McCrary, Justin, "Manipulation of the running variable in the regression discontinuity design: A density test," Journal of Econometrics, 2008, 142 (2), 698-714.

Pajares, Frank, "Self-Efficacy Beliefs and Mathematical Problem-Solving of Gifted Students," Contemporary Educational Psychology, 1996, 21 (4), 325-344.

Scalise, Alejandro, Mary Besterfield-Sacre, Larry Shuman, and Harvey Wolfe, "First Term Probation: Models for Identifying High Risk Students," Frontiers in Education Conference, 2000, 1, F1F/11-F1F/16.

Seaver, W. Burleigh and Richard J. Quarton, "Regression Discontinuity Analysis of Dean's List Effects," Journal of Educational Psychology, 1976, 68 (4), 459-465. 
Figure 1

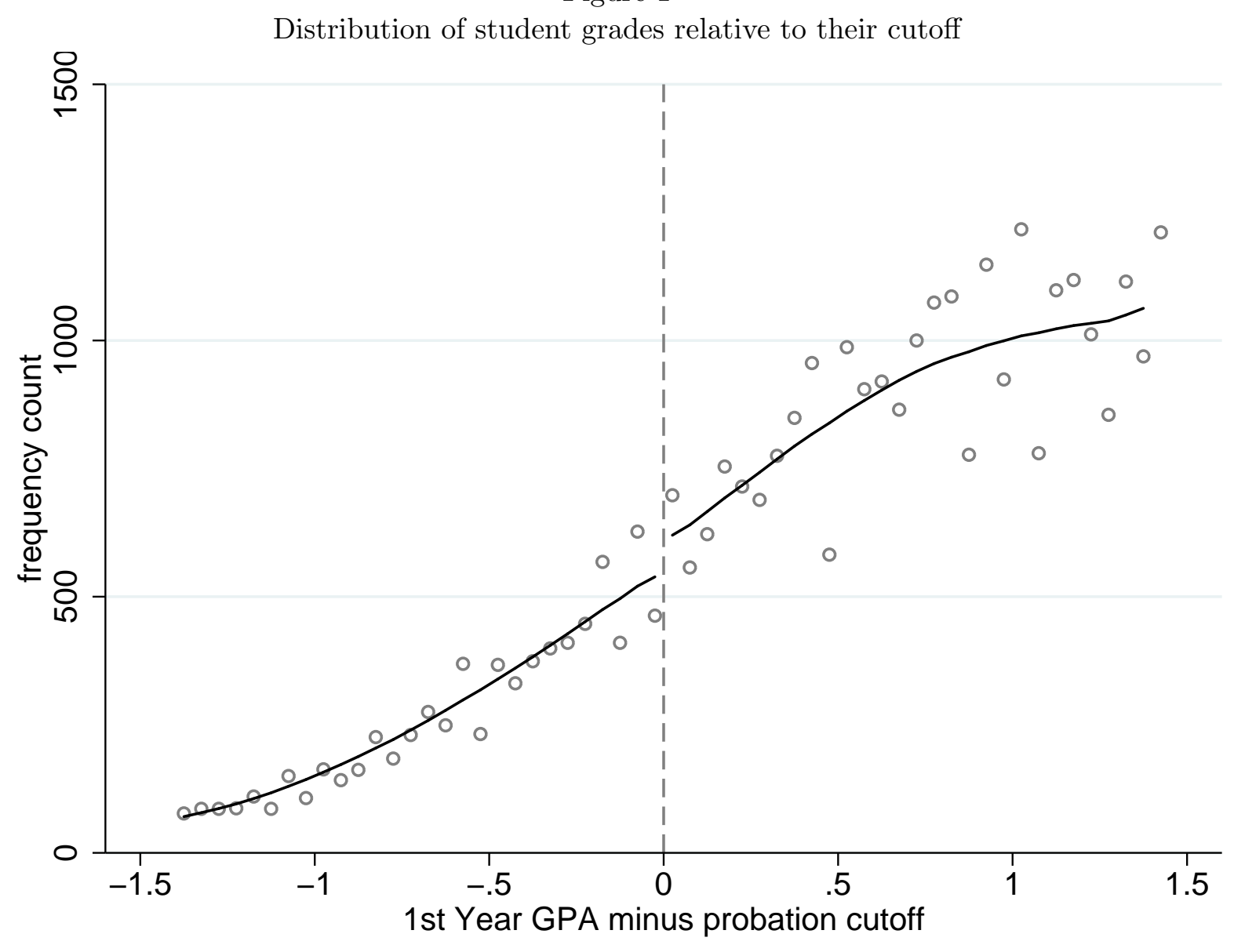

Notes: Each small hollow circle indicates the number of students with a distance from their cutoff within 0.025 points (including the lower but not the upper endpoint). Using each of these cells as an observation, the curve is predicted from local linear regressions with a bandwidth of 0.6 using triangular kernel weights. The estimated control mean is 608 and the estimated discontinuity is $58(\mathrm{p}$-value $=0.488)$ 
Figure 2

Estimated discontinuities in observable characteristics
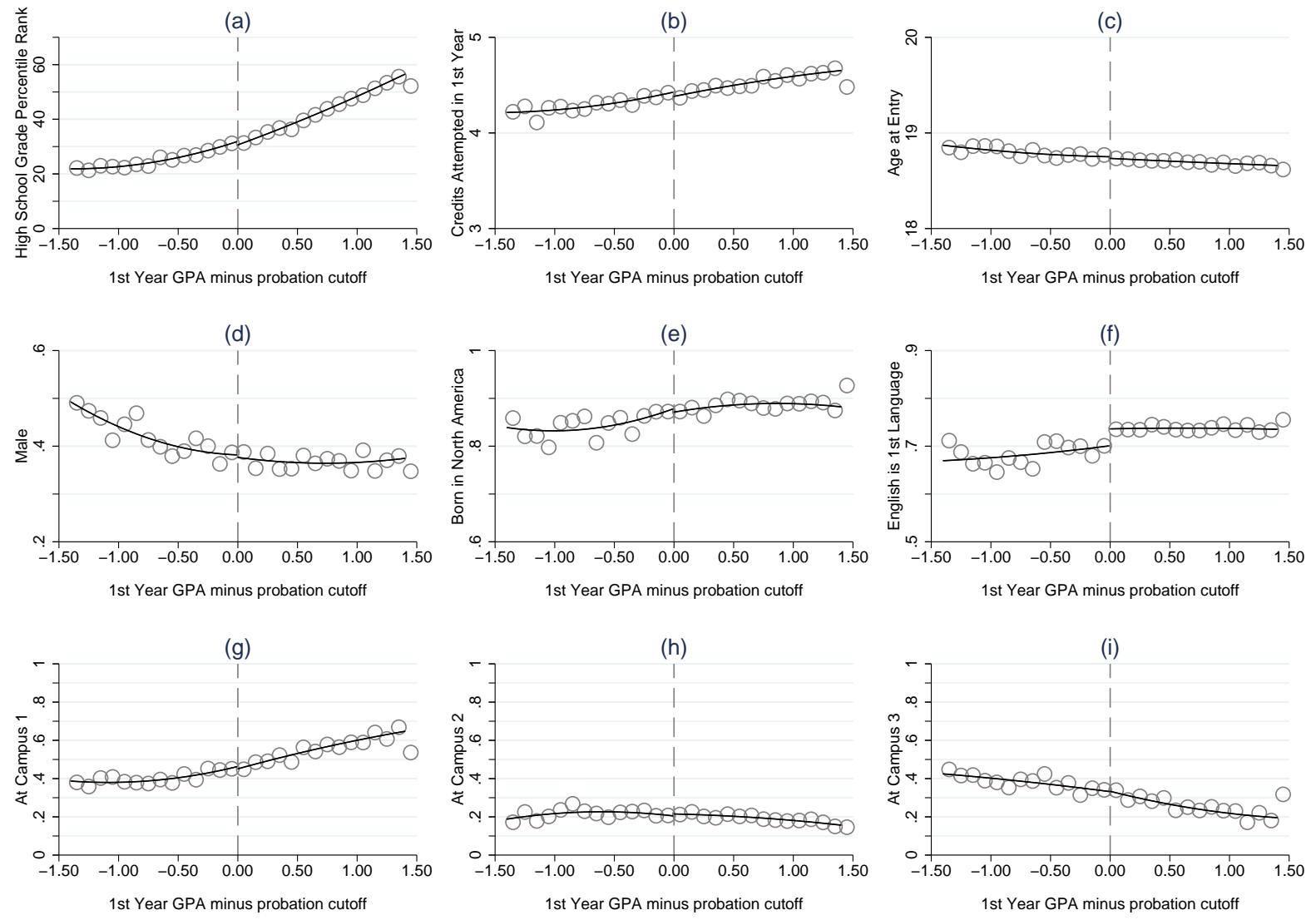

Notes: The curve is predicted based on second order polynomial that is flexible on each side of the cutoff. Each hollow circle is the mean of the outcome in an interval of 0.05 around the point (including the lower but not the upper endpoint). 
Figure 3

Probation status at the end of the 1st year

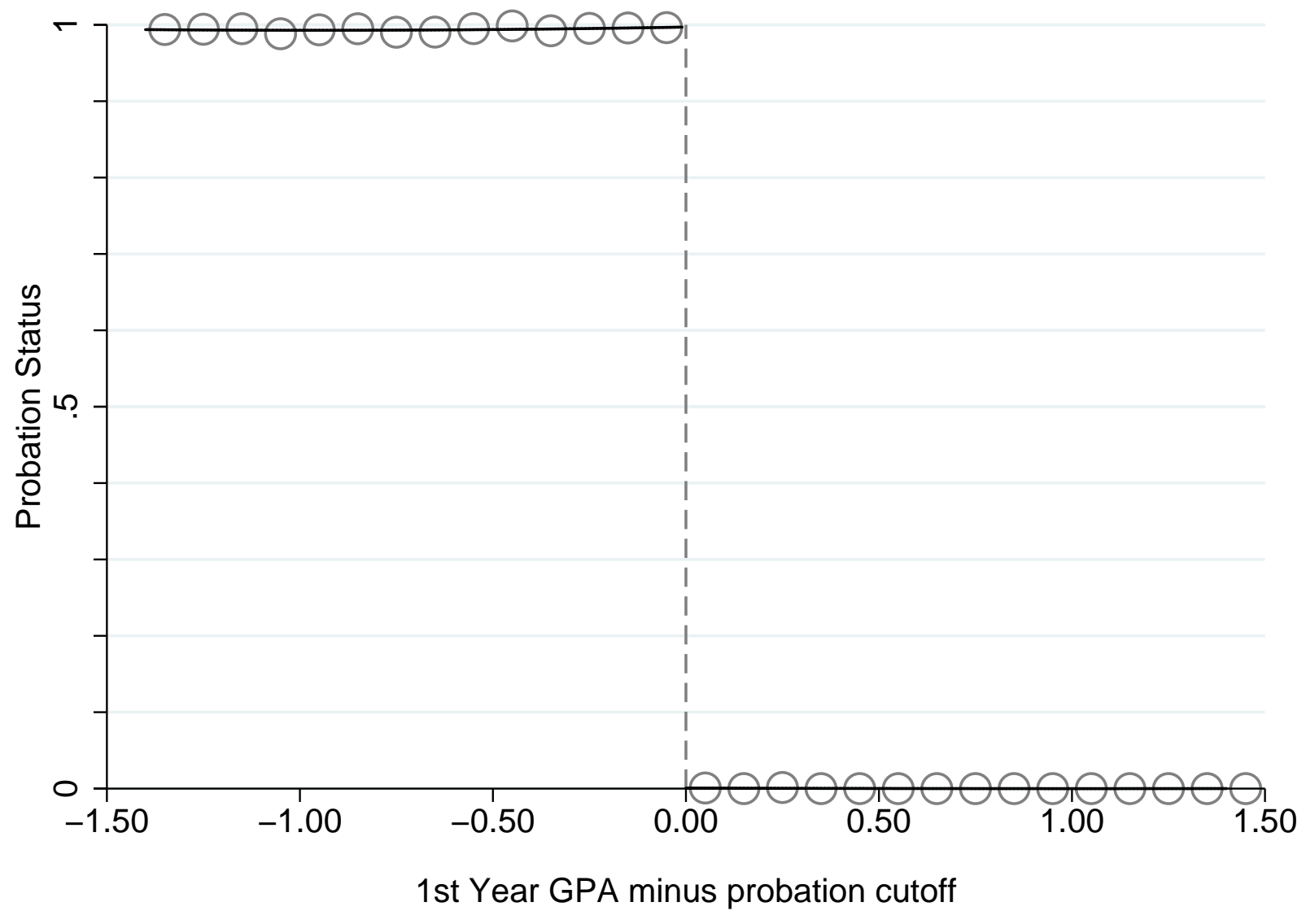

Notes: Same as Figure 2, 
Figure 4

Ever on academic probation

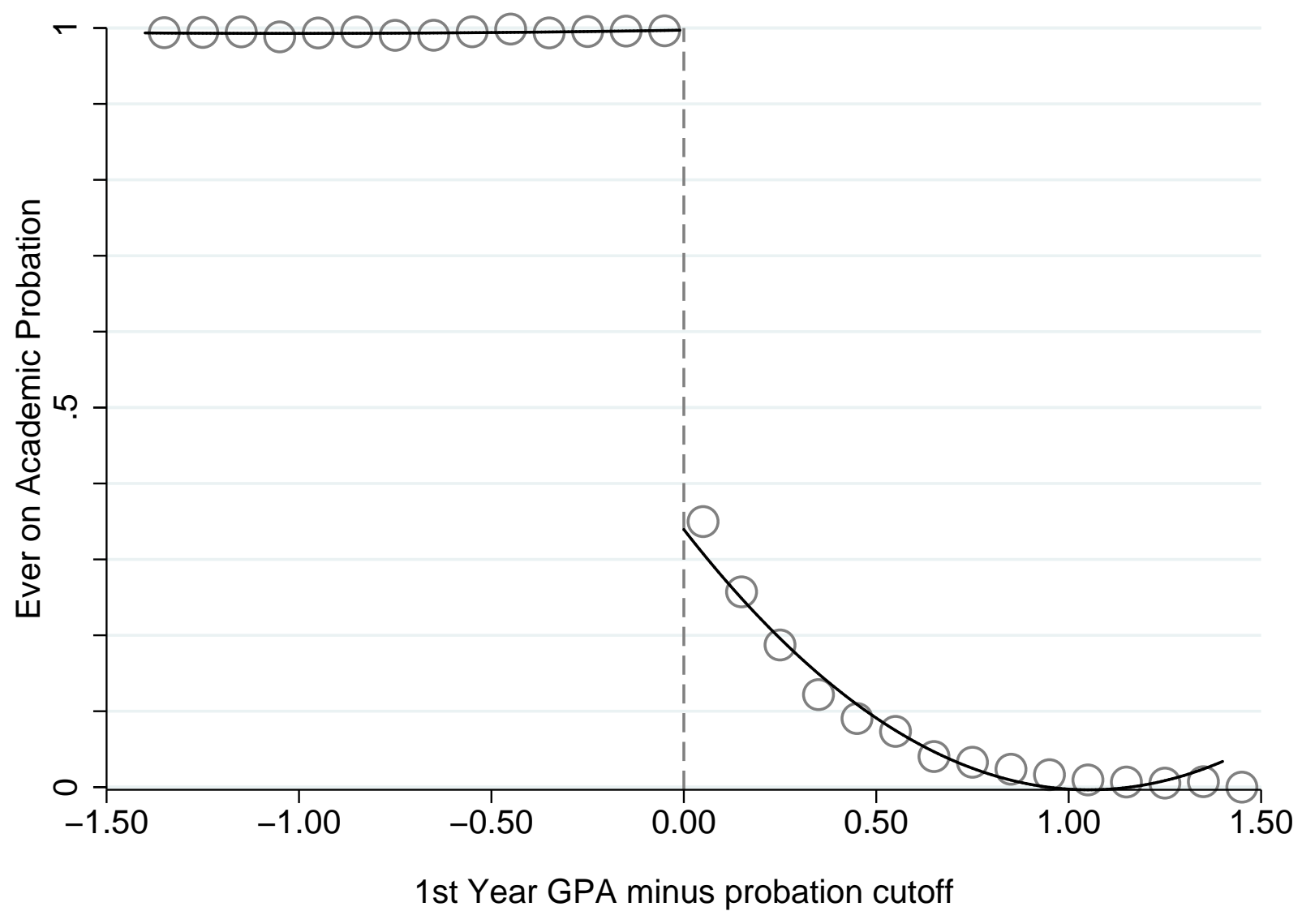

Notes: Same as Figure 2. 
Figure 5

Student voluntarily drops out of school at the end of the first year

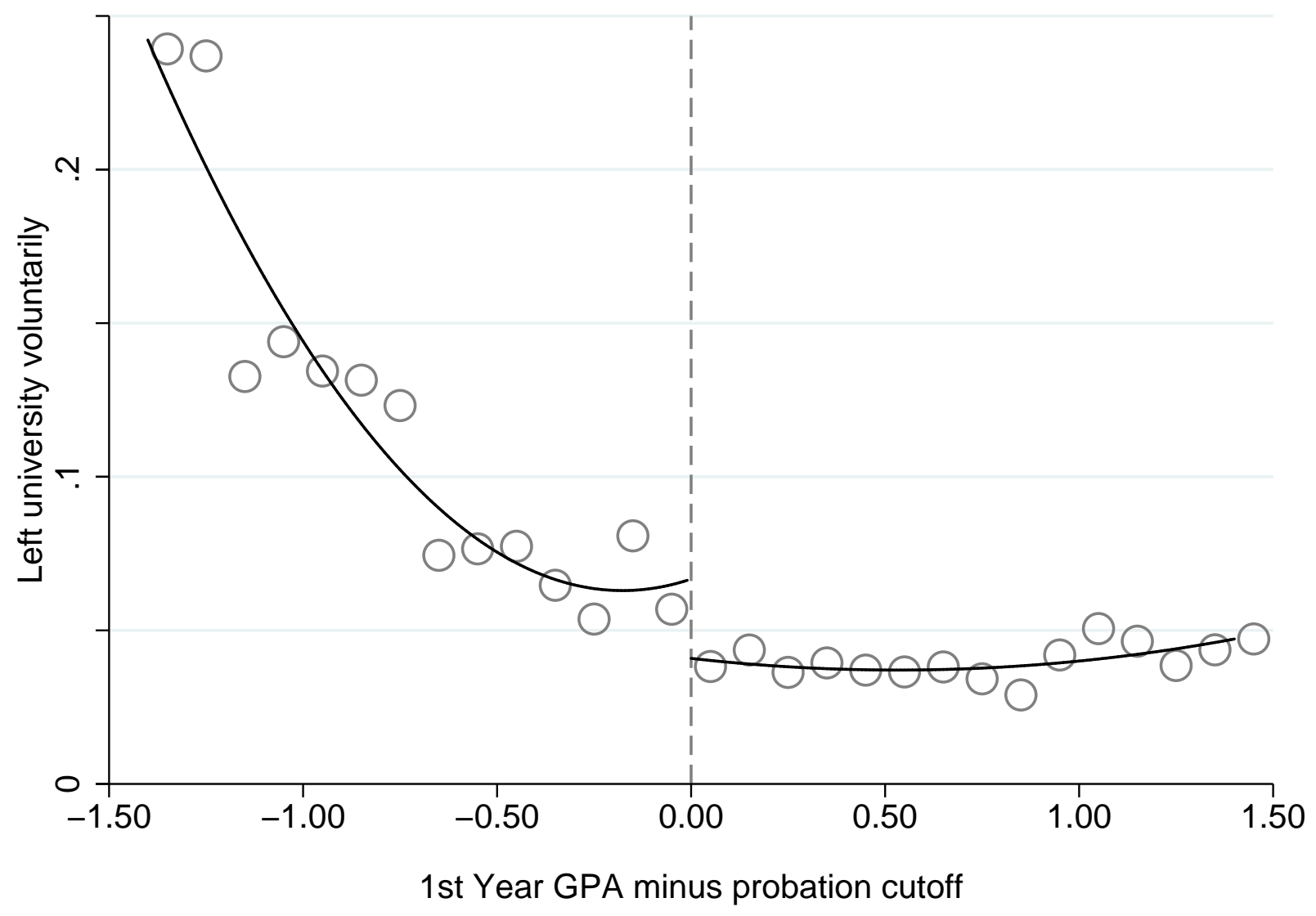

Notes: Same as Figure 2. 
Figure 6

Stratified results for voluntarily leaving school at the end of the first year

High school performance ranking
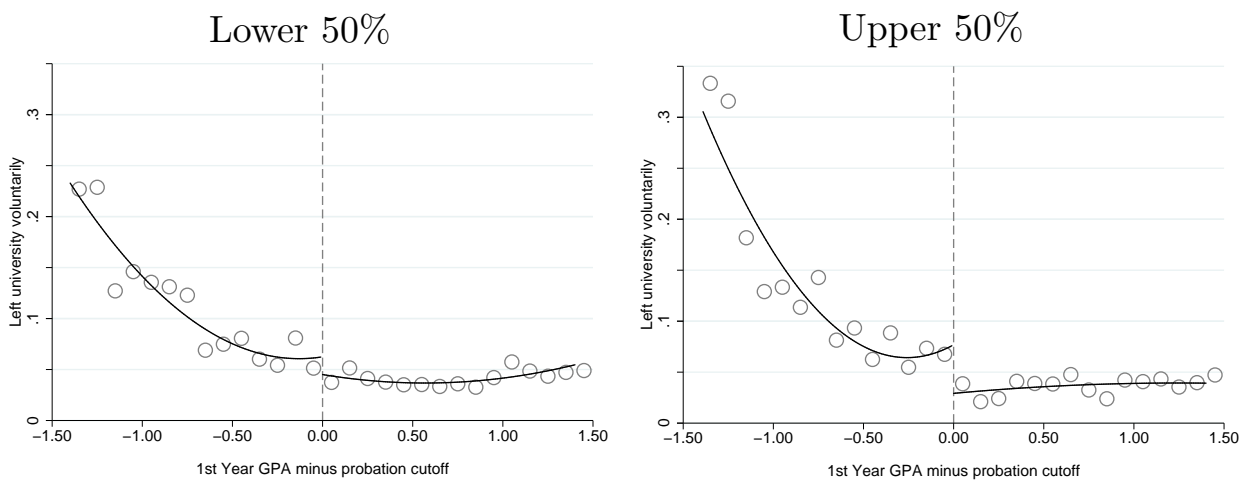

Gender
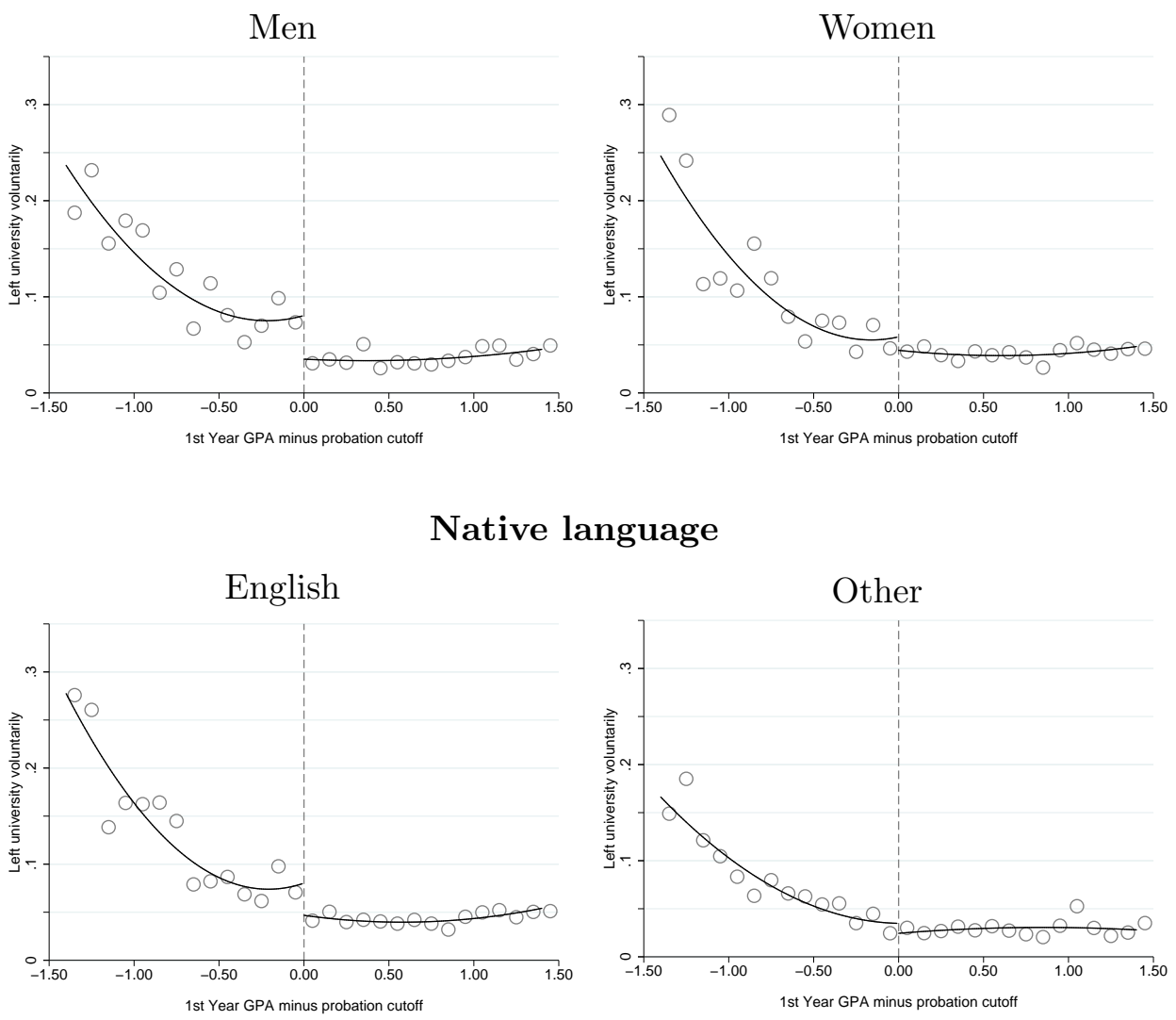

Notes: Same as Figure 2 
Figure 7

GPA in next enrolled term

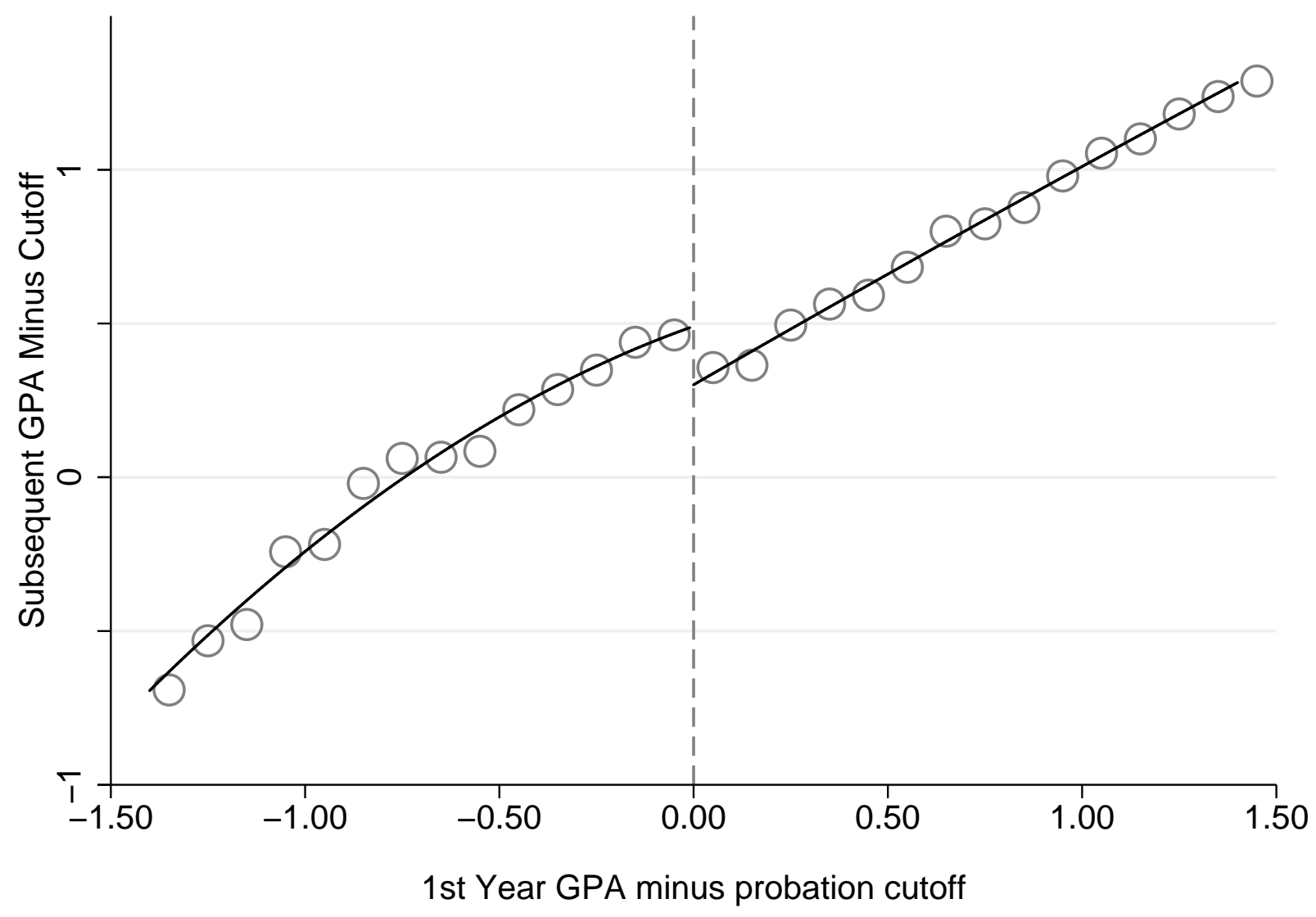

Notes: Same as Figure 2 
Figure 8

Stratified results for GPA in next enrolled term

\section{High school performance ranking}

Lower $50 \%$
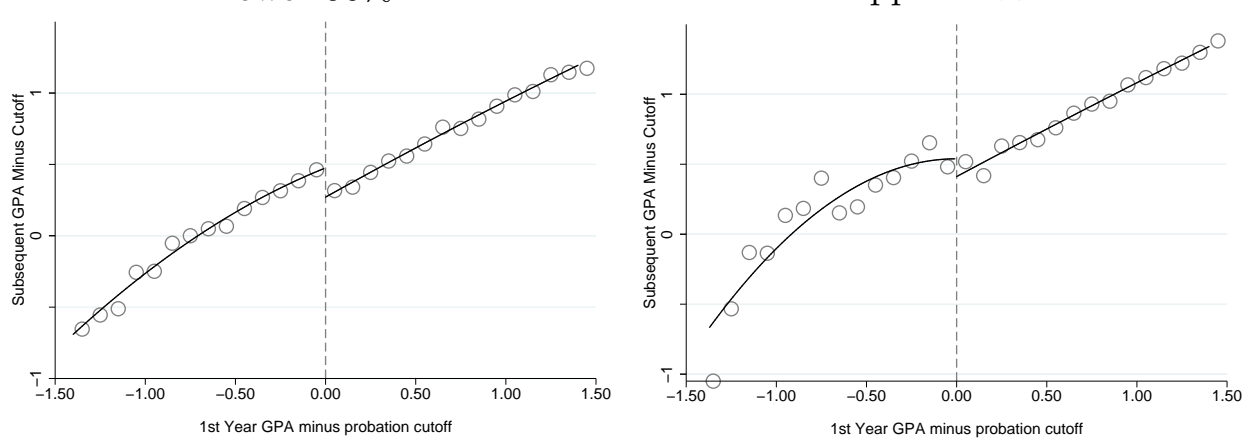

Gender
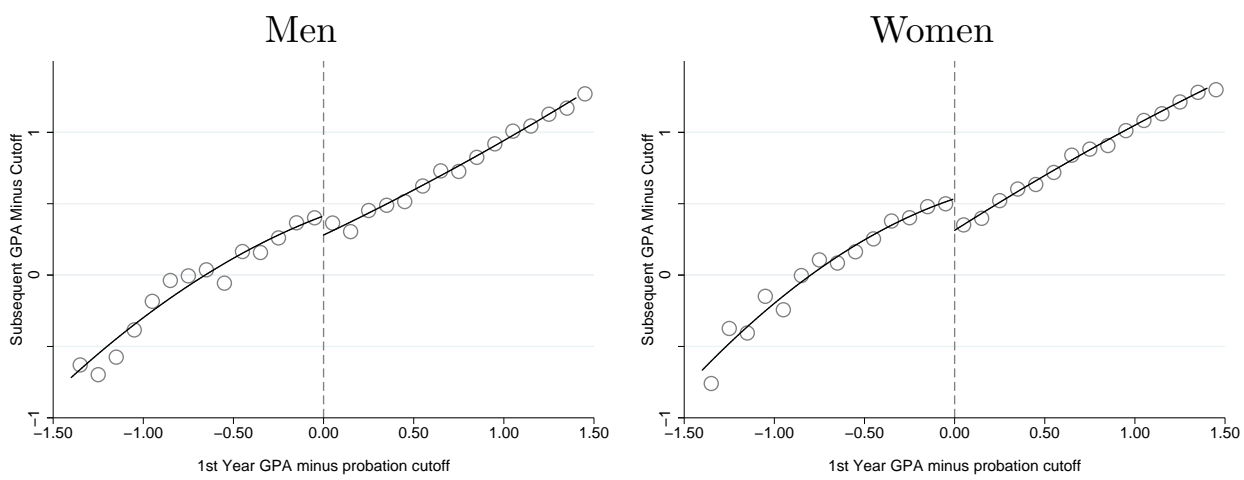

Native language
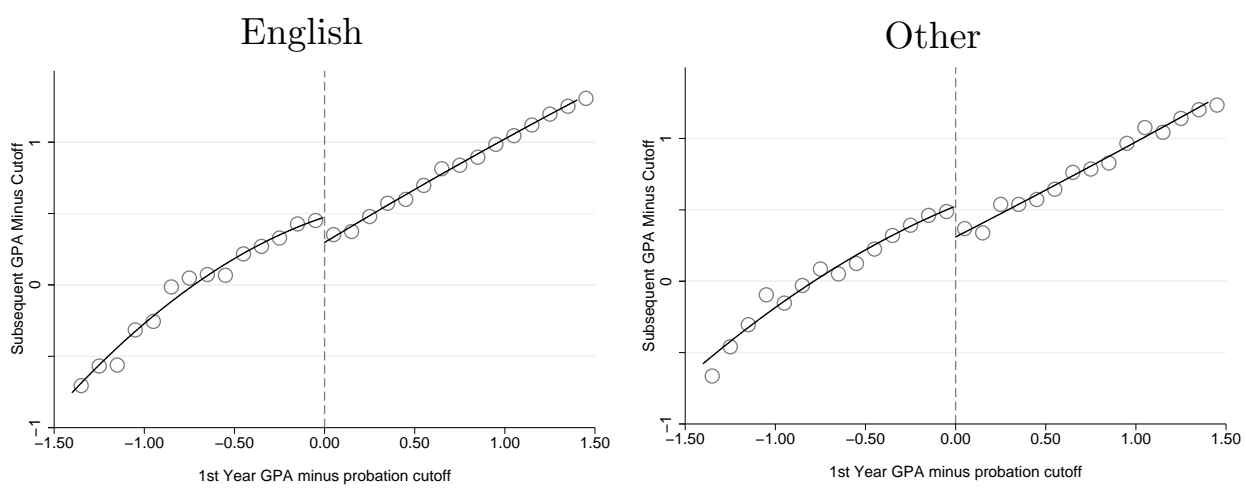

Notes: Same as Figure 2 
Figure 9

Ever suspended from the university

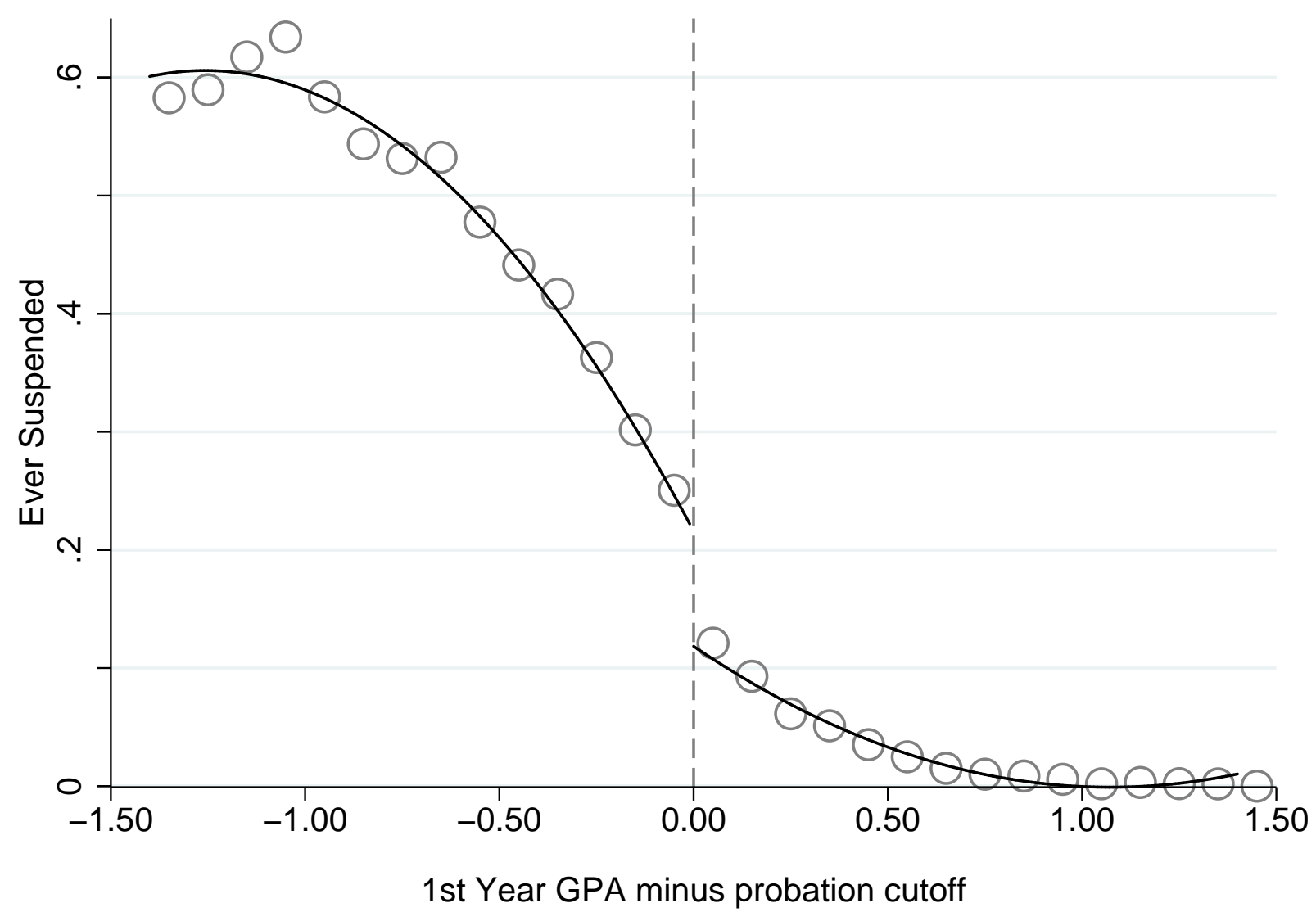

Notes: Same as Figure 2. 
Figure 10

Stratified results for ever being suspended

\section{High school performance ranking}
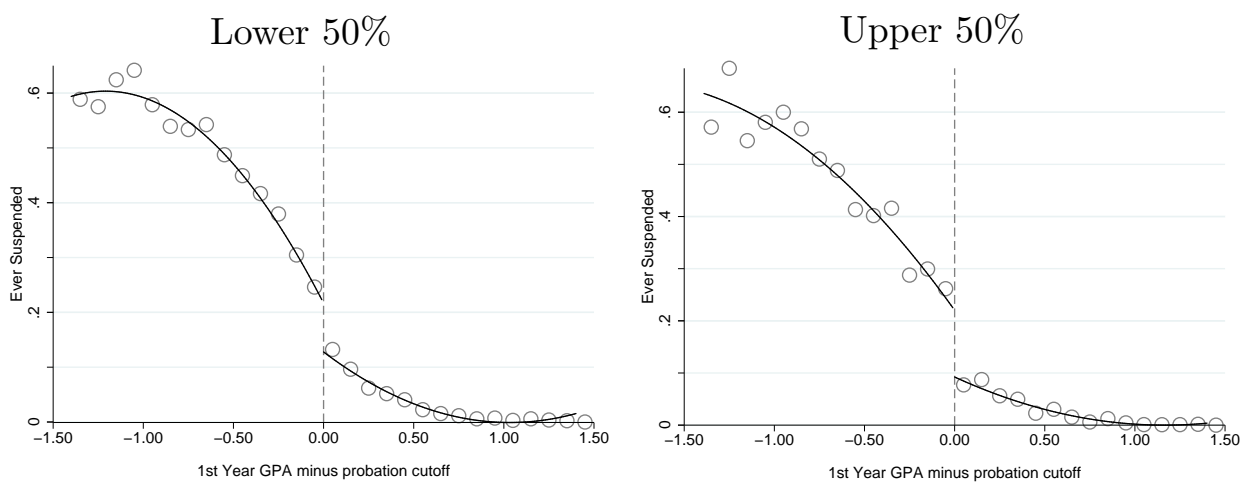

\section{Gender}
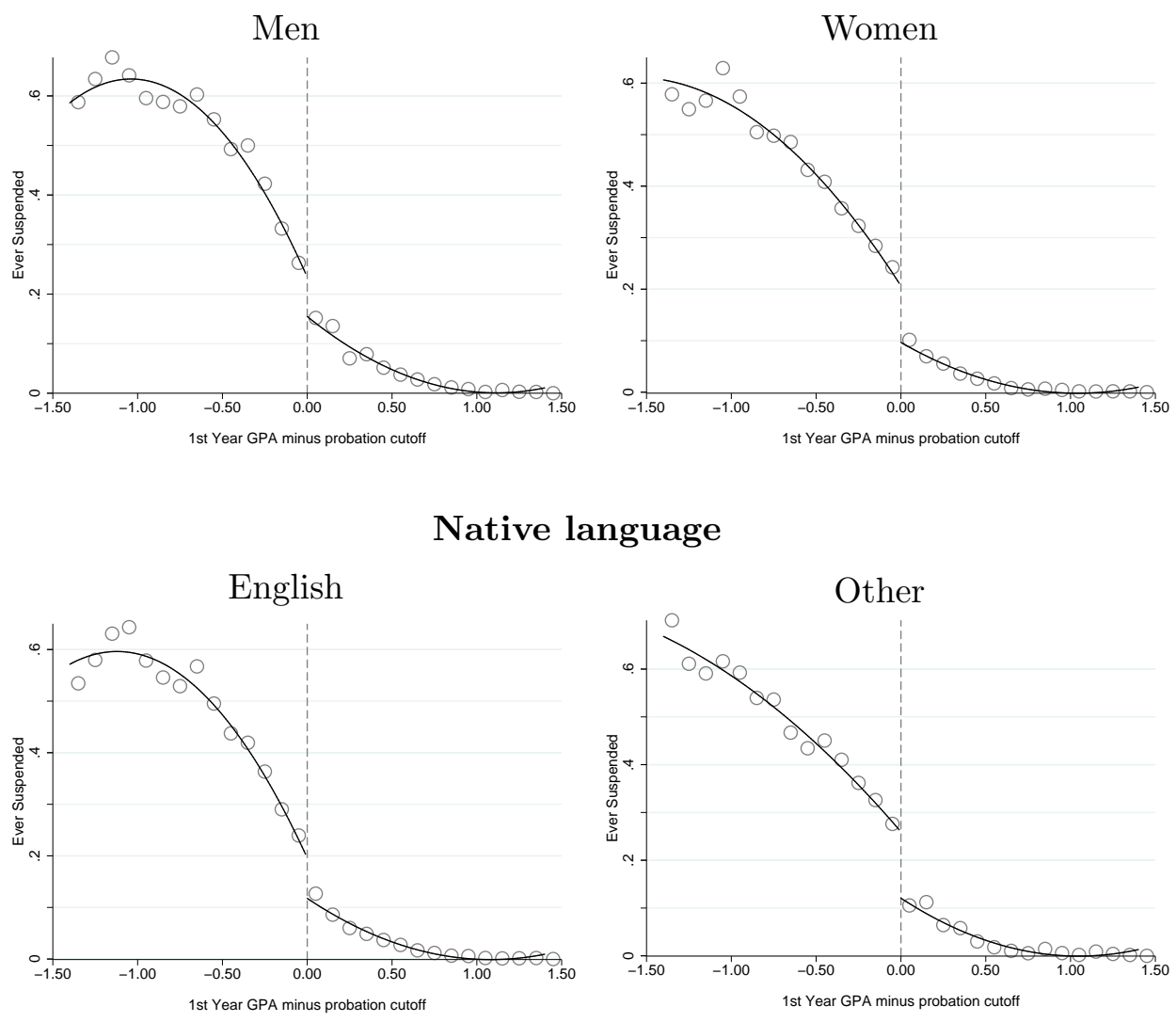

Notes: Same as Figure 2 
Figure 11

Graduation rates

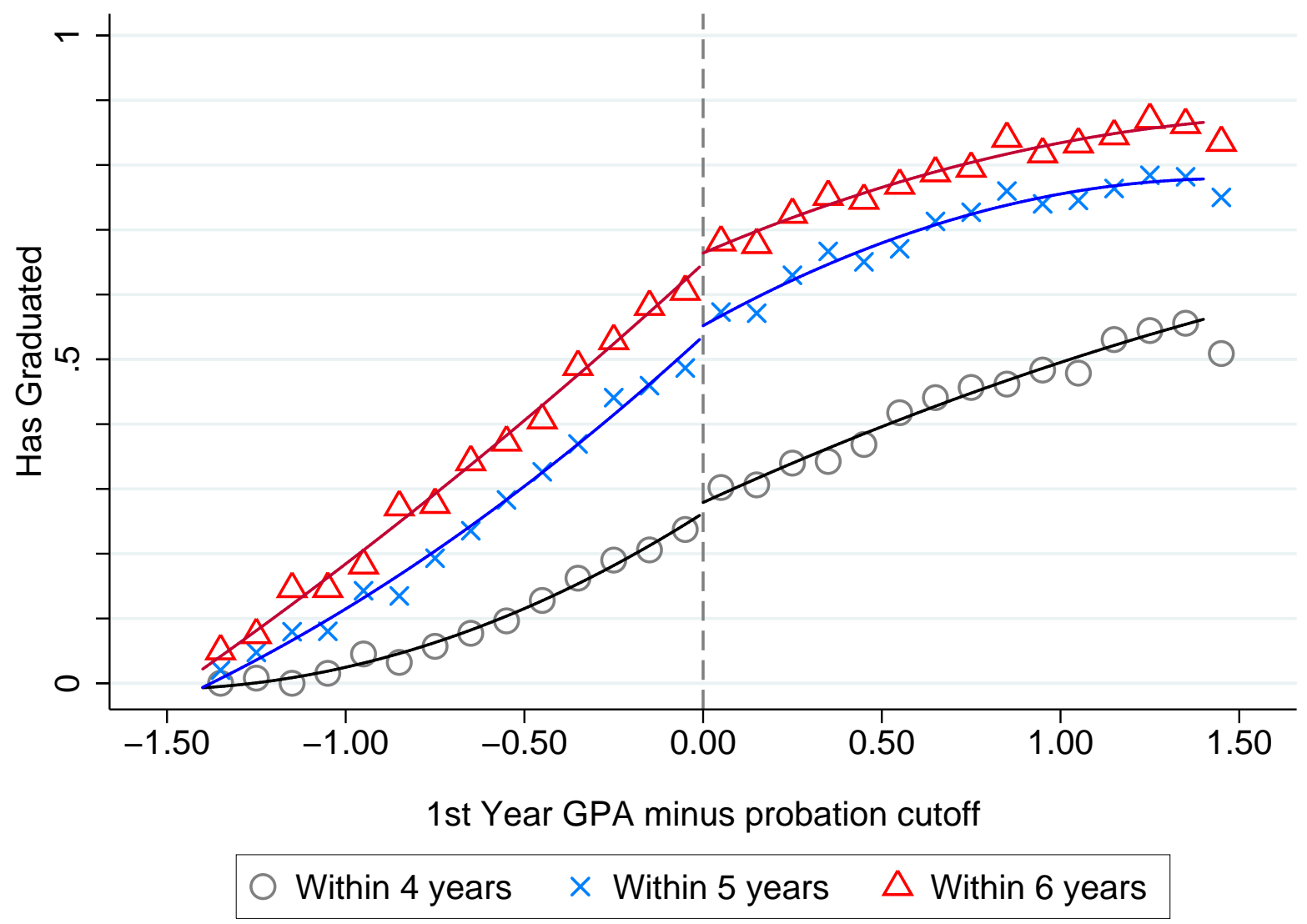

Notes: Same as Figure 2 
Figure 12

Stratified results for graduation rates

\section{High school performance ranking}

Lower $50 \%$

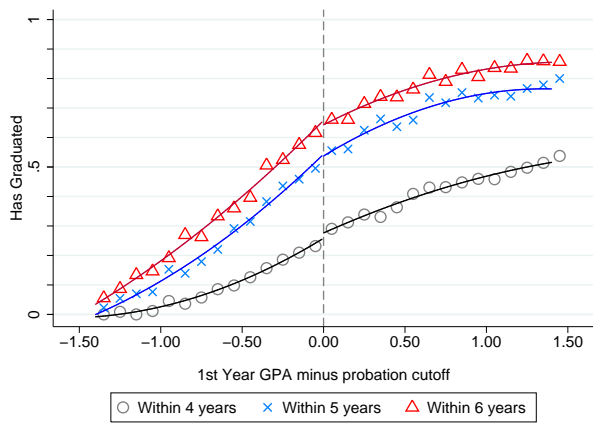

\section{Gender}

Men

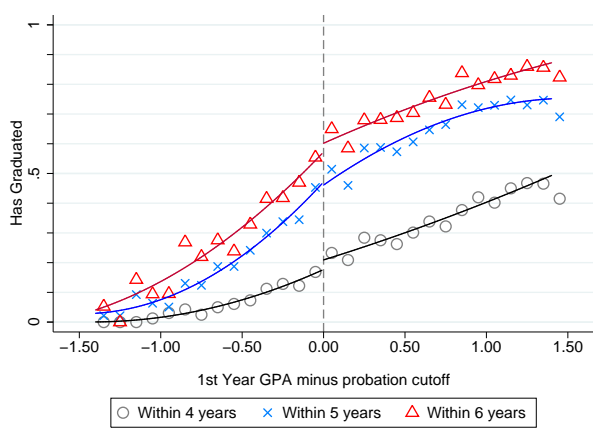

Upper $50 \%$

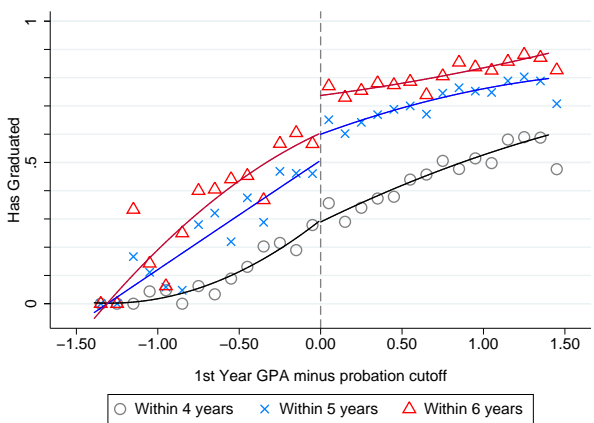

Within 4 years $\times$ Within 5 years $\Delta$ Within 6 years

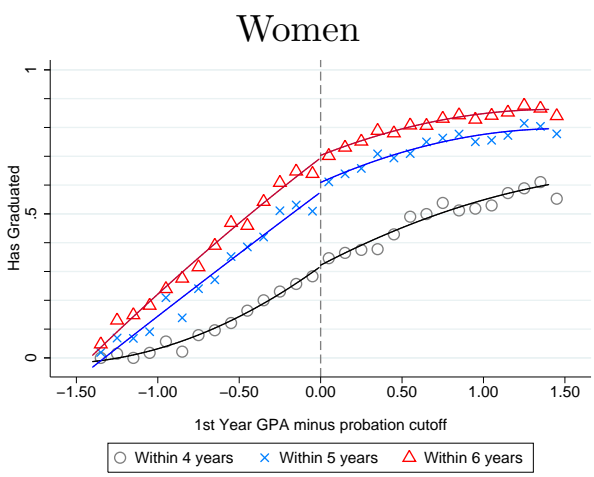

\section{Native language}

English

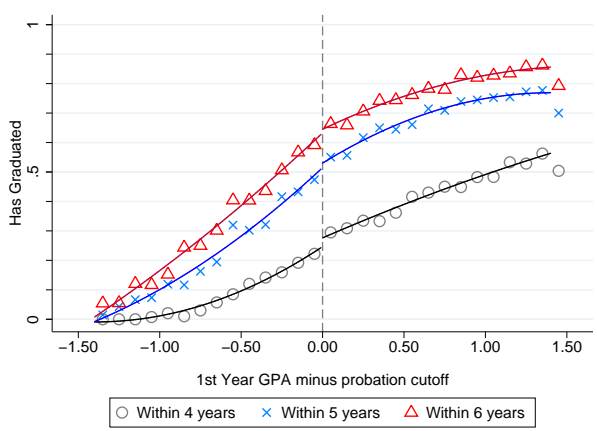

Other

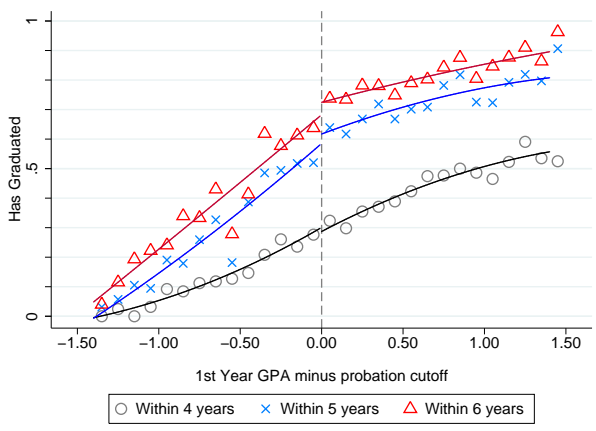

Notes: Same as Figure 2 
Figure 13

Predicted self-confidence (probability of returning after the first year)

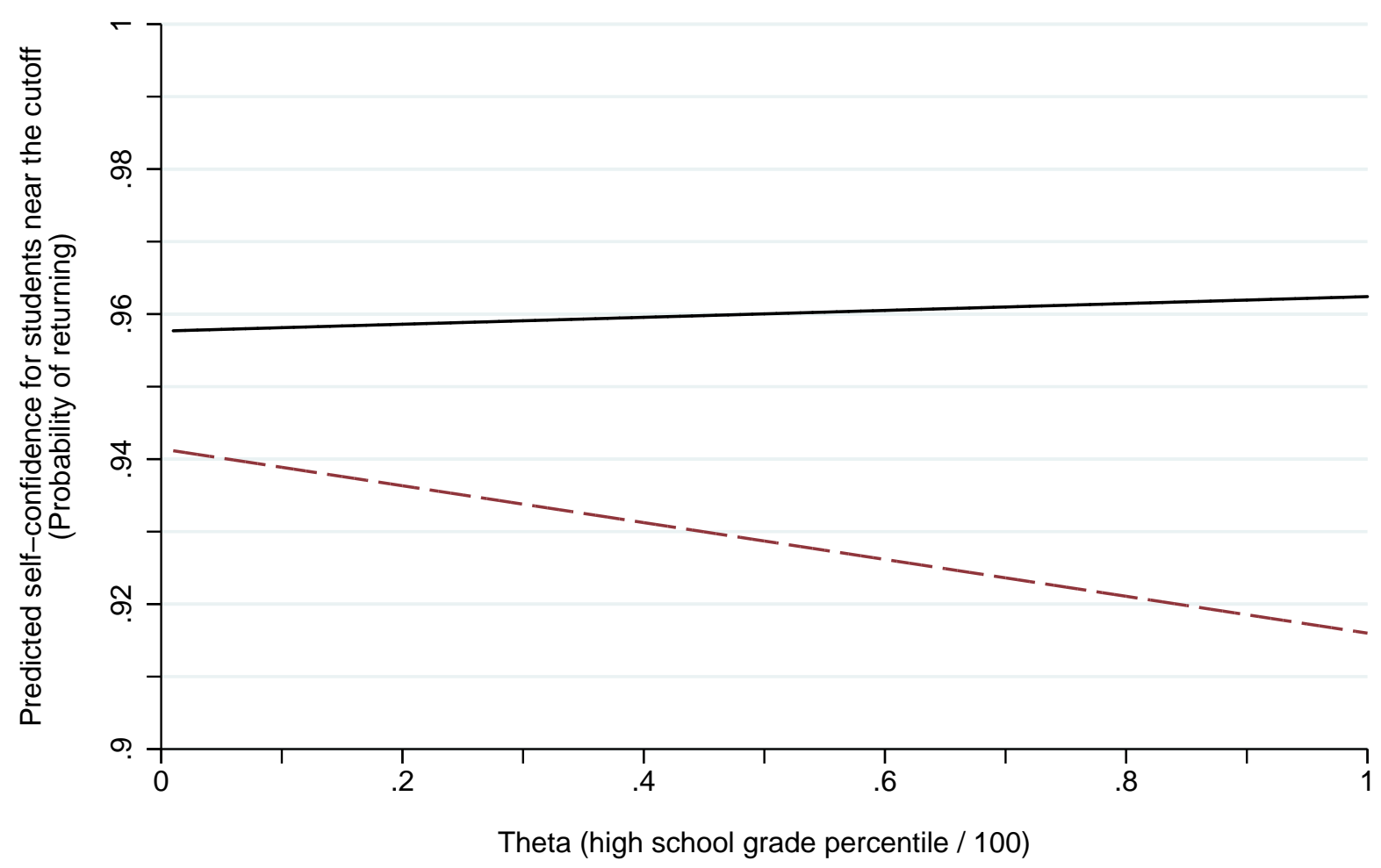

--- On Probation $\longrightarrow$ Not on Probation

Notes: The regression equation is

$$
\begin{aligned}
& \text { Return }_{i c}=m\left(\text { GPANORM }_{i c}^{\text {year } 1}\right)+\gamma_{1} \text { HSGRADE }_{i c}+\gamma_{2} 1\left(\text { GPANORM }_{i c}^{\text {year } 1}<0\right) \\
& +\gamma_{3} H S G R A D E_{i c} \times 1\left(G P A N O R M_{i c}^{\text {year } 1}<0\right)+u_{i c},
\end{aligned}
$$

where $m()$ is a second order polynomial flexible on each side of the academic probation cutoff. The lines plotted in the figure are the regression estimates evaluated at the cutoff $\left(G P A N O R M_{i c}^{\text {year } 1}=0\right)$. The resulting equation is:

$$
\begin{aligned}
& \operatorname{Pr}[\text { Return }]=0.95766 \quad+0.00005 \times H S G R A D E \quad-0.01624 \times A P \quad-0.00030 \times H S G R A D E \times A P \\
& \begin{array}{llll}
(0.00401) & (0.00005) & (0.00955)
\end{array}
\end{aligned}
$$

The curves are intended to demonstrate the relationship between ability and self-confidence within each group. Because the groups face different choice sets, the predicted probability of returning is not a valid measure of self-confidence across groups. 
Table 1

Summary Statistics

\begin{tabular}{lcc}
\hline & Mean & Standard Deviation \\
\hline & & \\
Characteristics & & \\
\hline High School Grade Percentile & 40.12 & 25.36 \\
Credits Attempted in First Year & 4.49 & 0.52 \\
Age at Entry & 18.71 & 0.73 \\
Male & 0.38 & 0.48 \\
English is First Language & 0.73 & 0.45 \\
Born in North America & 0.88 & 0.33 \\
At Campus 1 & 0.53 & 0.50 \\
At Campus 2 & 0.20 & 0.40 \\
At Campus 3 & 0.27 & 0.45 \\
& & \\
Outcomes & & \\
Distance from Cutoff in 1st Year & 0.48 & 0.65 \\
On Probation After 1st Year & 0.23 & 0.42 \\
Ever on Academic Probation & 0.28 & 0.45 \\
Left University after 1st Evaluation & 0.05 & 0.22 \\
Distance from Cutoff Next Evaluation & 0.71 & 0.84 \\
Ever Suspended & 0.12 & 0.32 \\
Graduated by Year 4 & 0.37 & 0.48 \\
Graduated by Year 5 & 0.62 & 0.49 \\
Graduated by Year 6 & 0.71 & 0.46 \\
& & \\
\hline
\end{tabular}

Note: The sample consists of the 32,697 students within 1.4 grade points of the cutoff in their first year. 
Table 2

Estimated Discontinuities in Observable Characteristics

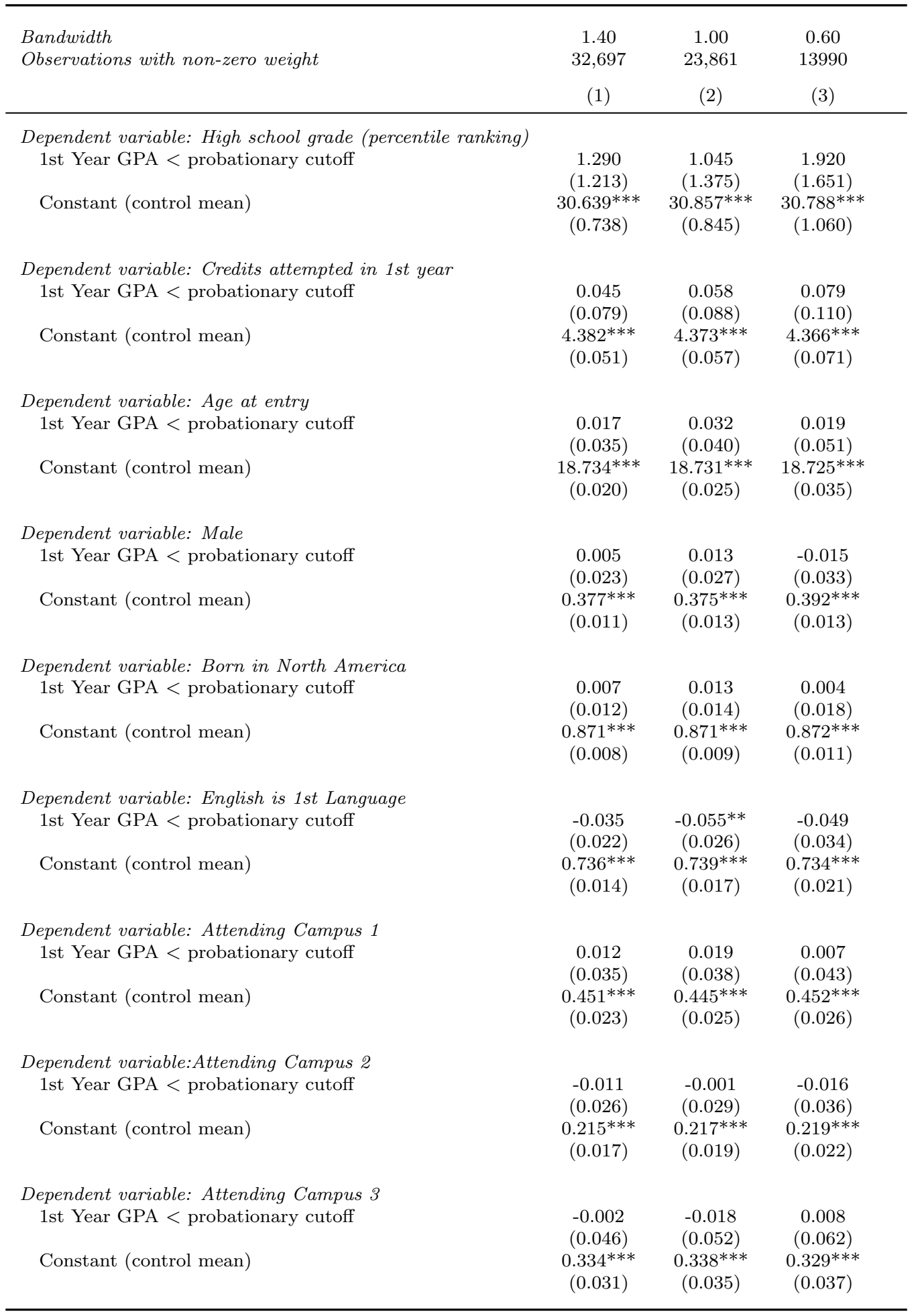

Notes: Same as Table 3

* significant at $10 \% ;{ }^{* *}$ significant at $5 \% ; * * *$ significant at $1 \%$ 
Table 3

Estimated Discontinuity in Probation Status

\begin{tabular}{|c|c|c|c|c|c|c|}
\hline $\begin{array}{l}\text { Bandwidth } \\
\text { Observations with non-zero weight } \\
\text { Control variables }\end{array}$ & $\begin{array}{c}1.40 \\
32,697 \\
\text { no } \\
(1)\end{array}$ & $\begin{array}{c}1.40 \\
32,697 \\
\text { yes } \\
(2)\end{array}$ & $\begin{array}{c}1.00 \\
23,861 \\
\text { no } \\
(3)\end{array}$ & $\begin{array}{c}1.00 \\
23,460 \\
\text { yes } \\
(4)\end{array}$ & $\begin{array}{c}0.60 \\
13,990 \\
\text { no } \\
(5)\end{array}$ & $\begin{array}{c}0.60 \\
13,990 \\
\text { yes } \\
(6)\end{array}$ \\
\hline \multicolumn{7}{|c|}{ Dependent variable: On academic probation after first evaluation } \\
\hline $\begin{array}{l}\text { 1st Year GPA < probationary cutoff } \\
\text { Constant (control mean) }\end{array}$ & $\begin{array}{c}0.996^{* * *} \\
(0.002) \\
0.001 \\
(0.000)\end{array}$ & $\begin{array}{c}0.996^{* * *} \\
(0.002) \\
- \\
-\end{array}$ & $\begin{array}{c}0.996^{* * *} \\
(0.002) \\
0.001 \\
(0.001)\end{array}$ & $\begin{array}{c}0.996^{* * *} \\
(0.002) \\
- \\
-\end{array}$ & $\begin{array}{c}0.997^{* * *} \\
(0.003) \\
0.000 \\
(0.001)\end{array}$ & $\begin{array}{c}0.996^{* * *} \\
(0.003) \\
- \\
-\end{array}$ \\
\hline \multicolumn{7}{|c|}{ Dependent variable: Ever on academic probation } \\
\hline $\begin{array}{l}\text { 1st Year GPA < probationary cutoff } \\
\text { Constant (control mean) }\end{array}$ & $\begin{array}{c}0.658^{* * *} \\
(0.012) \\
0.339^{* * *} \\
(0.012)\end{array}$ & $\begin{array}{c}0.658^{* * *} \\
(0.012) \\
- \\
-\end{array}$ & $\begin{array}{c}0.629 * * * \\
(0.012) \\
0.368^{* * *} \\
(0.012)\end{array}$ & $\begin{array}{c}0.628^{* * *} \\
(0.012) \\
- \\
-\end{array}$ & $\begin{array}{c}0.605^{* * *} \\
(0.015) \\
0.392^{* * *} \\
(0.015)\end{array}$ & $\begin{array}{c}0.607^{* * *} \\
(0.014) \\
- \\
-\end{array}$ \\
\hline
\end{tabular}

Notes: Estimated standard errors, clustered on GPA, are displayed in parentheses. Estimates are based on regressions including a second order polynomial in adjusted first year GPA flexible on each side of the cutoff using rectangular kernel weights and bandwidths noted in the table header. Constants are included in all specifications, though they but are not shown for models with covariates as they do not represent the control mean in such cases.

* significant at $10 \%$; ** significant at $5 \%$; *** significant at $1 \%$ 
Table 4

Estimated Effect on the Decision to Leave after the First Evaluation

\begin{tabular}{|c|c|c|c|c|c|c|}
\hline Bandwidth & 1.40 & 1.40 & 1.00 & 1.00 & 0.60 & 0.60 \\
\hline \multirow[t]{2}{*}{ Control variables } & no & yes & no & yes & no & yes \\
\hline & (1) & $(2)$ & (3) & $(4)$ & $(5)$ & (6) \\
\hline \multirow[t]{3}{*}{ 1st Year GPA < probationary cutoff } & $\begin{array}{c}0.026^{* * *} \\
(0.008)\end{array}$ & $\begin{array}{c}0.027^{* * *} \\
(0.008)\end{array}$ & $\begin{array}{c}0.023^{* * *} \\
(0.008)\end{array}$ & $\begin{array}{c}0.027^{* * *} \\
(0.009)\end{array}$ & $\begin{array}{c}0.022^{* * *} \\
(0.008)\end{array}$ & $\begin{array}{c}0.024^{* * *} \\
(0.009)\end{array}$ \\
\hline & $0.041^{* * *}$ & - & $0.043^{* * *}$ & - & $0.039^{* * *}$ & - \\
\hline & $(0.004)$ & - & $(0.004)$ & - & $(0.004)$ & - \\
\hline Observations with non-zero weight & 32,697 & 32,697 & 23,861 & 23,460 & 13,990 & 13,990 \\
\hline
\end{tabular}

Notes: Same as Table 3

* significant at $10 \% ;{ }^{* *}$ significant at $5 \%$; ${ }^{* *}$ significant at $1 \%$ 
Table 5

Estimated Effect on the Decision to Leave after the First Evaluation for Subgroups

\begin{tabular}{lccccccc}
\hline Subgroup & $\begin{array}{c}\text { HS Grades } \\
<\text { Median }\end{array}$ & $\begin{array}{c}\text { HS Grades } \\
>=\text { Median }\end{array}$ & Men & Women & $\begin{array}{c}\text { Native } \\
\text { English }\end{array}$ & $\begin{array}{c}\text { Non-native } \\
\text { English }\end{array}$ \\
& $(1)$ & $(2)$ & $(3)$ & $(4)$ & $(5)$ & $(6)$ \\
\hline 1st Year GPA < probationary cutoff & $0.017^{*}$ & $0.048^{* * *}$ & $0.045^{* * *}$ & 0.014 & $0.033^{* * *}$ & 0.010 \\
& $(0.009)$ & $(0.017)$ & $(0.014)$ & $(0.010)$ & $(0.011)$ & $(0.011)$ \\
Constant (control mean) & $0.045^{* * *}$ & $0.029^{* * *}$ & $0.035^{* * *}$ & $0.044^{* * *}$ & $\begin{array}{c}0.047^{* * *} \\
(0.005)\end{array}$ & $\begin{array}{c}(0.006) \\
(0.005)\end{array}$ & $\begin{array}{c}(0.006) \\
(0.006)\end{array}$ \\
Observations with non-zero weight & 20,996 & 11,314 & 12,301 & 20,396 & 23,739 & 8,958 \\
\hline
\end{tabular}

Notes: Estimated standard errors, clustered on GPA, are displayed in parentheses. Estimates are based on regressions including a second order polynomial in adjusted first year GPA flexible on each side of the cutoff using rectangular kernel weights and a bandwidth of 1.4.

* significant at $10 \% ;{ }^{* *}$ significant at $5 \% ; * * *$ significant at $1 \%$ 
Table 6

Estimated Discontinuities in Subsequent GPA

\begin{tabular}{|c|c|c|c|c|c|c|}
\hline Bandwidth & 1.40 & 1.40 & 1.00 & 1.00 & 0.60 & 0.60 \\
\hline \multirow[t]{2}{*}{ Control variables } & no & yes & no & yes & no & yes \\
\hline & $(1)$ & $(2)$ & $(3)$ & $(4)$ & $(5)$ & $(6)$ \\
\hline \multicolumn{7}{|l|}{ No adjustment for students not returning } \\
\hline 1st Year GPA < probationary cutoff & $\begin{array}{c}0.190^{* * *} \\
(0.027)\end{array}$ & $\begin{array}{c}0.185^{* * *} \\
(0.026)\end{array}$ & $\begin{array}{c}0.217^{* * *} \\
(0.032)\end{array}$ & $\begin{array}{c}0.210^{* * *} \\
(0.031)\end{array}$ & $\begin{array}{c}0.191^{* * *} \\
(0.039)\end{array}$ & $\begin{array}{c}0.181^{* * *} \\
(0.038)\end{array}$ \\
\hline \multirow[t]{2}{*}{ Constant (control mean) } & $0.301^{* * *}$ & - & $0.298^{* * *}$ & - & $0.308^{* * *}$ & - \\
\hline & $(0.016)$ & - & $(0.021)$ & - & $(0.025)$ & - \\
\hline Observations with non-zero weight & 29,745 & 29,745 & 21,628 & 21,259 & 12,626 & 12,626 \\
\hline \multicolumn{7}{|c|}{ Assuming students who left after being placed on AP would have performed the same in year 2 as in year 1} \\
\hline 1st Year GPA < probationary cutoff & $\begin{array}{c}0.128^{* * *} \\
(0.024)\end{array}$ & $\begin{array}{c}0.125^{* * *} \\
(0.022)\end{array}$ & $\begin{array}{c}0.149^{* * *} \\
(0.029)\end{array}$ & $\begin{array}{c}0.142^{* * *} \\
(0.027)\end{array}$ & $\begin{array}{c}0.130^{* * *} \\
(0.035)\end{array}$ & $\begin{array}{c}0.123^{* * *} \\
(0.033)\end{array}$ \\
\hline \multirow[t]{2}{*}{ Constant (control mean) } & $0.301^{* * *}$ & - & $0.298^{* * *}$ & - & $0.308^{* * *}$ & - \\
\hline & $(0.016)$ & - & $(0.021)$ & - & $(0.025)$ & - \\
\hline Observations with non-zero weight & 30,985 & 30,985 & 22,639 & 22,258 & 13,289 & 13,289 \\
\hline \multicolumn{7}{|c|}{ Assuming students on AP who left would have GPA change in the 10th percentile of similar students } \\
\hline 1st Year GPA < probationary cutoff & $\begin{array}{c}0.062^{* *} \\
(0.025)\end{array}$ & $\begin{array}{c}0.058^{* *} \\
(0.023)\end{array}$ & $\begin{array}{c}0.082^{* * *} \\
(0.029)\end{array}$ & $\begin{array}{c}0.074^{* * *} \\
(0.027)\end{array}$ & $\begin{array}{c}0.066^{*} \\
(0.035)\end{array}$ & $\begin{array}{c}0.058^{*} \\
(0.032)\end{array}$ \\
\hline \multirow[t]{2}{*}{ Constant (control mean) } & $0.301^{* * *}$ & - & $0.298^{* * *}$ & - & $0.308^{* * *}$ & - \\
\hline & $(0.016)$ & - & $(0.021)$ & - & $(0.025)$ & - \\
\hline Observations with non-zero weight & 30,985 & 30,985 & 22,639 & 22,258 & 13,289 & 13,289 \\
\hline
\end{tabular}

Notes: Estimated standard errors, clustered on GPA, are displayed in parentheses. Estimates are based on regressions including a second order polynomial in adjusted first year GPA flexible on each side of the cutoff using rectangular kernel weights and bandwidths noted in the table header. Constants are included in all specifications, though they but are not shown for models with covariates as they do not represent the control mean in such cases. In the third panel, students that left after being placed on probation have their second year GPA imputed as their first year GPA minus 0.52 - only $10 \%$ of students within 0.6 of the cutoff who return after being placed on probation do worse.

* significant at $10 \% ;{ }^{* *}$ significant at $5 \%$; ** significant at $1 \%$ 
Table 7

Estimated Discontinuities in Subsequent GPA for Subgroups

\begin{tabular}{|c|c|c|c|c|c|c|}
\hline Subgroup & $\begin{array}{c}\text { HS Grades } \\
<\text { Median } \\
(1)\end{array}$ & $\begin{array}{c}\text { HS Grades } \\
>=\text { Median } \\
(2)\end{array}$ & $\begin{array}{l}\text { Men } \\
(3)\end{array}$ & $\begin{array}{c}\text { Women } \\
\text { (4) }\end{array}$ & $\begin{array}{c}\text { Native } \\
\text { English } \\
(5)\end{array}$ & $\begin{array}{c}\text { Non-native } \\
\text { English } \\
(6)\end{array}$ \\
\hline 1st Year GPA < probationary cutoff & $\begin{array}{c}0.205^{* * *} \\
(0.030)\end{array}$ & $\begin{array}{c}0.127^{*} \\
(0.076)\end{array}$ & $\begin{array}{c}0.134^{* * *} \\
(0.046)\end{array}$ & $\begin{array}{c}0.222^{* * *} * \\
(0.035)\end{array}$ & $\begin{array}{c}0.177^{* * * *} \\
(0.036)\end{array}$ & $\begin{array}{c}0.216^{* * *} \\
(0.052)\end{array}$ \\
\hline Constant (control mean) & $\begin{array}{c}0.271^{* * *} \\
(0.019)\end{array}$ & $\begin{array}{c}0.412^{* * *} \\
(0.035)\end{array}$ & $\begin{array}{c}0.280^{* * *} \\
(0.025)\end{array}$ & $\begin{array}{c}0.313^{* * *} \\
(0.023)\end{array}$ & $\begin{array}{c}0.310^{* * *} \\
(0.032)\end{array}$ & $\begin{array}{c}0.323 * * * \\
(0.037)\end{array}$ \\
\hline Observations with non-zero weight & 18,866 & 10,524 & 11,111 & 18,634 & 21,443 & 8,302 \\
\hline
\end{tabular}

Notes: Same as Table 5

* significant at $10 \% ;{ }^{* *}$ significant at $5 \%$;** significant at $1 \%$ 
Table 8

Estimated Effects on Ever Being Suspended

\begin{tabular}{lcccccc}
\hline Bandwidth & 1.40 & 1.40 & 1.00 & 1.00 & 0.60 & 0.60 \\
Control variables & no & yes & no & yes & no & yes \\
& $(1)$ & $(2)$ & $(3)$ & $(4)$ & $(5)$ & $(6)$ \\
\hline Effect of probation after the first year & & & & & & \\
1st Year GPA < probationary cutoff & $0.097^{* * *}$ & $0.097^{* * *}$ & $0.091^{* * *}$ & $0.087^{* * *}$ & $0.084^{* * *}$ & $0.085^{* * *}$ \\
& $(0.013)$ & $(0.014)$ & $(0.015)$ & $(0.016)$ & $(0.020)$ & $(0.022)$ \\
Constant (control mean) & $0.118^{* * *}$ & - & $0.126^{* * *}$ & - & $0.128^{* * *}$ & - \\
& $(0.006)$ & - & $(0.006)$ & - & $(0.008)$ & - \\
Observations with non-zero weight & 32,697 & 32,697 & 23,861 & 23,460 & 13,990 & 13,990 \\
& & & & & & \\
Effect of ever being placed on probation & & & & & & \\
Ever on probation & $0.148^{* * *}$ & $0.148^{* * *}$ & $0.144^{* * *}$ & $0.139^{* * *}$ & $0.139^{* * *}$ & $0.141^{* * *}$ \\
& $(0.019)$ & $(0.020)$ & $(0.024)$ & $(0.026)$ & $(0.033)$ & $(0.036)$ \\
Constant (control mean) & $0.068^{* * *}$ & - & $0.073^{* * *}$ & - & $0.073^{* * *}$ & - \\
Observations with non-zero weight & $(0.010)$ & - & $(0.012)$ & - & $(0.017)$ & - \\
& 32,697 & 32,697 & 23,861 & 23,460 & 13,990 & 13,990 \\
\hline
\end{tabular}

Notes: Estimated standard errors, clustered on GPA, are displayed in parentheses. Estimates are based on regressions including a second order polynomial in adjusted first year GPA flexible on each side of the cutoff using rectangular kernel weights and bandwidths noted in the table header. Constants are included in all specifications, though they but are not shown for models with covariates as they do not represent the control mean in such cases. The effect of ever being placed on probation is based on a 2SLS estimate as described in Section 5

* significant at $10 \%$; ** significant at $5 \%$; *** significant at $1 \%$ 
Table 9

Estimated Effects on Ever Being Suspended for Subgroups

\begin{tabular}{|c|c|c|c|c|c|c|}
\hline Subgroup & $\begin{array}{c}\text { HS Grades } \\
<\text { Median } \\
(1)\end{array}$ & $\begin{array}{c}\text { HS Grades } \\
>=\text { Median } \\
(2)\end{array}$ & $\begin{array}{l}\text { Men } \\
(3)\end{array}$ & $\begin{array}{l}\text { Women } \\
\text { (4) }\end{array}$ & $\begin{array}{c}\text { Native } \\
\text { English } \\
(5)\end{array}$ & $\begin{array}{c}\text { Non-native } \\
\text { English } \\
(6)\end{array}$ \\
\hline \multicolumn{7}{|l|}{ Effect of probation after the first year } \\
\hline 1st Year GPA < probationary cutoff & $\begin{array}{c}0.644^{* * *} \\
(0.012)\end{array}$ & $\begin{array}{c}0.128^{* * *} * \\
(0.026)\end{array}$ & $\begin{array}{c}0.080^{* * *} \\
(0.019)\end{array}$ & $\begin{array}{c}0.110^{* * *} \\
(0.018)\end{array}$ & $\begin{array}{c}0.079^{* * *} \\
(0.019)\end{array}$ & $\begin{array}{c}0.139 * * * \\
(0.020)\end{array}$ \\
\hline Constant (control mean) & $\begin{array}{c}0.355^{* * *} \\
(0.012)\end{array}$ & $\begin{array}{c}0.092^{* * *} \\
(0.009)\end{array}$ & $\begin{array}{c}0.155^{* * *} \\
(0.011)\end{array}$ & $\begin{array}{c}0.097 * * * \\
(0.007)\end{array}$ & $\begin{array}{c}0.118^{* * *} \\
(0.006)\end{array}$ & $\begin{array}{c}0.121^{* * *} \\
(0.010)\end{array}$ \\
\hline Observations with non-zero weight & 20,996 & 11,314 & 12,301 & 20,396 & 23,739 & 8,958 \\
\hline \multicolumn{7}{|l|}{ Effect of ever being placed on probation } \\
\hline Ever on probation & $\begin{array}{c}0.138^{* * *} \\
(0.025)\end{array}$ & $\begin{array}{c}0.184^{* * *} \\
(0.037)\end{array}$ & $\begin{array}{c}0.131^{* * *} \\
(0.030)\end{array}$ & $\begin{array}{c}0.159^{* * *} \\
(0.025)\end{array}$ & $\begin{array}{c}0.118^{* * *} \\
(0.028)\end{array}$ & $\begin{array}{c}0.220^{* * * *} \\
(0.030)\end{array}$ \\
\hline Constant (control mean) & $\begin{array}{c}0.079^{* * *} \\
(0.012)\end{array}$ & $\begin{array}{c}0.038^{* *} \\
(0.016)\end{array}$ & $\begin{array}{c}0.104^{* * *} \\
(0.019)\end{array}$ & $\begin{array}{c}0.047^{* * *} \\
(0.011)\end{array}$ & $\begin{array}{c}0.079^{* * *} \\
(0.012)\end{array}$ & $\begin{array}{c}0.040^{* *} \\
(0.017)\end{array}$ \\
\hline Observations with non-zero weight & 20,996 & 11,314 & 12,301 & 20,396 & 23,739 & 8,958 \\
\hline
\end{tabular}

Notes: Estimated standard errors, clustered on GPA, are displayed in parentheses. Estimates are based on regressions including a second order polynomial in adjusted first year GPA flexible on each side of the cutoff using rectangular kernel weights and a bandwidth of 1.4. The effect of ever being placed on probation is based on a 2SLS estimate as described in Section 5

* significant at $10 \% ; * *$ significant at $5 \%$;** significant at $1 \%$ 
Table 10

Estimated Effects on Graduation

\begin{tabular}{|c|c|c|c|c|c|c|}
\hline $\begin{array}{l}\text { Bandwidth } \\
\text { Control variables }\end{array}$ & $\begin{array}{c}1.40 \\
\text { no } \\
(1)\end{array}$ & $\begin{array}{c}1.40 \\
\text { yes } \\
(2)\end{array}$ & $\begin{array}{c}1.00 \\
\text { no } \\
(3)\end{array}$ & $\begin{array}{c}1.00 \\
\text { yes } \\
(4)\end{array}$ & $\begin{array}{c}0.60 \\
\text { no } \\
(5)\end{array}$ & $\begin{array}{c}0.60 \\
\text { yes } \\
(6)\end{array}$ \\
\hline \multicolumn{7}{|c|}{ Dependent variable: Graduated after 4 years } \\
\hline \multicolumn{7}{|l|}{ Effect of probation after the first year } \\
\hline 1st Year GPA < probationary cutoff & $\begin{array}{l}-0.016 \\
(0.017)\end{array}$ & $\begin{array}{l}-0.022 \\
(0.015)\end{array}$ & $\begin{array}{l}-0.017 \\
(0.020)\end{array}$ & $\begin{array}{l}-0.025 \\
(0.018)\end{array}$ & $\begin{array}{c}-0.052^{* *} \\
(0.025)\end{array}$ & $\begin{array}{c}-0.060^{* * *} \\
(0.022)\end{array}$ \\
\hline Constant (control mean) & $\begin{array}{c}0.279 * * * \\
(0.011)\end{array}$ & $\begin{array}{l}- \\
-\end{array}$ & $\begin{array}{c}0.278^{* * *} \\
(0.012)\end{array}$ & $\begin{array}{l}- \\
-\end{array}$ & $\begin{array}{c}0.308^{* * *} \\
(0.014)\end{array}$ & $\begin{array}{l}- \\
-\end{array}$ \\
\hline Observations with non-zero weight & 23,449 & 23,449 & 17,302 & 16,996 & 10,281 & 10,281 \\
\hline \multicolumn{7}{|l|}{ Effect of ever being on probation } \\
\hline Ever on probation & $\begin{array}{l}-0.026 \\
(0.027)\end{array}$ & $\begin{array}{l}-0.035 \\
(0.024)\end{array}$ & $\begin{array}{l}-0.028 \\
(0.032)\end{array}$ & $\begin{array}{l}-0.042 \\
(0.029)\end{array}$ & $\begin{array}{c}-0.089^{* *} \\
(0.043)\end{array}$ & $\begin{array}{c}-0.102^{* * *} \\
(0.038)\end{array}$ \\
\hline Constant (control mean) & $\begin{array}{c}0.288^{* * * *} \\
(0.019)\end{array}$ & $\begin{array}{l}- \\
-\end{array}$ & $\begin{array}{c}0.289^{* * *} \\
(0.022)\end{array}$ & - & $\begin{array}{c}0.344^{* * *} \\
(0.027)\end{array}$ & - \\
\hline Observations with non-zero weight & 23,449 & 23,449 & 17,302 & 16,996 & 10,281 & 10,281 \\
\hline \multicolumn{7}{|c|}{ Dependent variable: Graduated after 5 years } \\
\hline \multicolumn{7}{|l|}{ Effect of probation after the first year } \\
\hline 1st Year GPA $<$ probationary cutoff & $\begin{array}{l}-0.016 \\
(0.025)\end{array}$ & $\begin{array}{l}-0.021 \\
(0.022)\end{array}$ & $\begin{array}{l}-0.020 \\
(0.029)\end{array}$ & $\begin{array}{l}-0.029 \\
(0.026)\end{array}$ & $\begin{array}{l}-0.032 \\
(0.039)\end{array}$ & $\begin{array}{l}-0.040 \\
(0.036)\end{array}$ \\
\hline Constant (control mean) & $\begin{array}{c}0.552^{* * * *} \\
(0.015)\end{array}$ & $\begin{array}{l}- \\
-\end{array}$ & $\begin{array}{c}0.548^{* * *} \\
(0.018)\end{array}$ & - & $\begin{array}{c}0.549^{* * *} \\
(0.025)\end{array}$ & - \\
\hline Observations with non-zero weight & 19,806 & 19,806 & 14,669 & 14,407 & 8,753 & 8,753 \\
\hline \multicolumn{7}{|l|}{ Effect of ever being on probation } \\
\hline Ever on probation & $\begin{array}{l}-0.026 \\
(0.039)\end{array}$ & $\begin{array}{l}-0.033 \\
(0.034)\end{array}$ & $\begin{array}{l}-0.033 \\
(0.048)\end{array}$ & $\begin{array}{l}-0.048 \\
(0.043)\end{array}$ & $\begin{array}{l}-0.055 \\
(0.066)\end{array}$ & $\begin{array}{l}-0.068 \\
(0.060)\end{array}$ \\
\hline Constant (control mean) & $\begin{array}{c}0.561^{* * * *} \\
(0.026)\end{array}$ & $\begin{array}{l}- \\
-\end{array}$ & $\begin{array}{c}0.561^{* * *} \\
(0.033)\end{array}$ & $\begin{array}{l}- \\
-\end{array}$ & $\begin{array}{c}0.572^{* * *} \\
(0.046)\end{array}$ & - \\
\hline Observations with non-zero weight & 19,806 & 19,806 & 14,669 & 14,407 & 8,753 & 8,753 \\
\hline \multicolumn{7}{|c|}{ Dependent variable: Graduated after 6 years } \\
\hline \multicolumn{7}{|l|}{ Effect of probation after the first year } \\
\hline 1st Year GPA $<$ probationary cutoff & $\begin{array}{l}-0.016 \\
(0.022)\end{array}$ & $\begin{array}{l}-0.023 \\
(0.021)\end{array}$ & $\begin{array}{l}-0.017 \\
(0.027)\end{array}$ & $\begin{array}{l}-0.025 \\
(0.025)\end{array}$ & $\begin{array}{l}-0.031 \\
(0.037)\end{array}$ & $\begin{array}{l}-0.043 \\
(0.035)\end{array}$ \\
\hline Constant (control mean) & $\begin{array}{c}0.664^{* * * *} \\
(0.015)\end{array}$ & - & $\begin{array}{c}0.661^{* * * *} \\
(0.019)\end{array}$ & - & $\begin{array}{c}0.662^{* * * *} \\
(0.028)\end{array}$ & - \\
\hline Observations with non-zero weight & 16,683 & 16,683 & 12,452 & 12,228 & 7,465 & 7,465 \\
\hline \multicolumn{7}{|l|}{ Effect of ever being on probation } \\
\hline Ever on probation & $\begin{array}{l}-0.026 \\
(0.035)\end{array}$ & $\begin{array}{l}-0.036 \\
(0.033)\end{array}$ & $\begin{array}{l}-0.028 \\
(0.044)\end{array}$ & $\begin{array}{l}-0.042 \\
(0.042)\end{array}$ & $\begin{array}{l}-0.054 \\
(0.063)\end{array}$ & $\begin{array}{c}-0.072 \\
(0.059)\end{array}$ \\
\hline Constant (control mean) & $\begin{array}{c}0.674^{* * *} \\
(0.025)\end{array}$ & - & $\begin{array}{c}0.672^{* * *} \\
(0.034)\end{array}$ & - & $\begin{array}{c}0.685^{* * *} * \\
(0.050)\end{array}$ & - \\
\hline Observations with non-zero weight & 16,683 & 16,683 & 12,452 & 12,228 & 7,465 & 7,465 \\
\hline
\end{tabular}

Notes: Estimated standard errors, clustered on GPA, are displayed in parentheses. Estimates are based on regressions including a second order polynomial in adjusted first year GPA flexible on each side of the cutoff using rectangular kernel weights and bandwidths noted in the table header. Constants are included in all specifications, though they but are not shown for models with covariates as they do not represent the control mean in such cases. The effect of ever being placed on probation is based on a 2SLS estimate as described in Section 5

* significant at $10 \%$;* significant at $5 \%$;** significant at $1 \%$ 
Table 11

Estimated Effects of Ever Being Placed on Probation on Graduation for Subgroups

\begin{tabular}{|c|c|c|c|c|c|c|}
\hline Subgroup & $\begin{array}{c}\text { HS Grades } \\
<\text { Median } \\
(1)\end{array}$ & $\begin{array}{c}\text { HS Grades } \\
>=\text { Median } \\
(2)\end{array}$ & $\begin{array}{l}\text { Men } \\
(3)\end{array}$ & $\begin{array}{c}\text { Women } \\
\text { (4) }\end{array}$ & $\begin{array}{c}\text { Native } \\
\text { English } \\
(5)\end{array}$ & $\begin{array}{c}\text { Non-native } \\
\text { English } \\
(6)\end{array}$ \\
\hline \multicolumn{7}{|c|}{ Dependent variable: Has graduated after 4 years } \\
\hline Ever on probation & $\begin{array}{l}-0.029 \\
(0.030)\end{array}$ & $\begin{array}{c}0.010 \\
(0.062)\end{array}$ & $\begin{array}{l}-0.056 \\
(0.044)\end{array}$ & $\begin{array}{l}-0.006 \\
(0.040)\end{array}$ & $\begin{array}{l}-0.047 \\
(0.030)\end{array}$ & $\begin{array}{c}0.021 \\
(0.050)\end{array}$ \\
\hline Constant (control mean) & $\begin{array}{c}0.287^{* * *} \\
(0.034)\end{array}$ & $\begin{array}{c}0.286^{* * *} * \\
(0.046)\end{array}$ & $\begin{array}{c}0.232^{* * *} \\
(0.033)\end{array}$ & $\begin{array}{c}0.324^{* * *} \\
(0.023)\end{array}$ & $\begin{array}{c}0.293^{* * *} * \\
(0.021)\end{array}$ & $\begin{array}{c}0.279 * * * \\
(0.034)\end{array}$ \\
\hline Observations with non-zero weight & 15,621 & 7,556 & 8,899 & 14,550 & 17,305 & 6,144 \\
\hline \multicolumn{7}{|c|}{ Dependent variable: Has graduated after 5 years } \\
\hline Ever on probation & $\begin{array}{c}0.010 \\
(0.045)\end{array}$ & $\begin{array}{c}-0.135^{* *} \\
(0.068)\end{array}$ & $\begin{array}{c}0.018 \\
(0.064)\end{array}$ & $\begin{array}{l}-0.051 \\
(0.045)\end{array}$ & $\begin{array}{l}-0.024 \\
(0.043)\end{array}$ & $\begin{array}{l}-0.050 \\
(0.055)\end{array}$ \\
\hline Constant (control mean) & $\begin{array}{c}0.533^{* * *} \\
(0.034)\end{array}$ & $\begin{array}{c}0.641^{* * *} \\
(0.041)\end{array}$ & $\begin{array}{c}0.454^{* * *} \\
(0.047)\end{array}$ & $\begin{array}{c}0.626^{* * *} \\
(0.027)\end{array}$ & $\begin{array}{c}0.539^{* * *} \\
(0.027)\end{array}$ & $\begin{array}{c}0.635^{* * *} \\
(0.038)\end{array}$ \\
\hline Observations with non-zero weight & 13,178 & 6,399 & 7,508 & 12,298 & 14,674 & 5,132 \\
\hline \multicolumn{7}{|c|}{ Dependent variable: Has graduated after 6 years } \\
\hline Ever on probation & $\begin{array}{c}0.024 \\
(0.041)\end{array}$ & $\begin{array}{c}-0.198^{* *} \\
(0.079)\end{array}$ & $\begin{array}{l}-0.051 \\
(0.066)\end{array}$ & $\begin{array}{c}-0.014 \\
(0.044)\end{array}$ & $\begin{array}{l}-0.020 \\
(0.045)\end{array}$ & $\begin{array}{l}-0.067 \\
(0.052)\end{array}$ \\
\hline Constant (control mean) & $\begin{array}{c}0.634^{* * *} \\
(0.033)\end{array}$ & $\begin{array}{c}0.801^{* * *} \\
(0.042)\end{array}$ & $\begin{array}{c}0.623^{* * *} \\
(0.050)\end{array}$ & $\begin{array}{c}0.708^{* * *} \\
(0.028)\end{array}$ & $\begin{array}{c}0.652^{* * *} \\
(0.027)\end{array}$ & $\begin{array}{c}0.749 * * * \\
(0.039)\end{array}$ \\
\hline Observations with non-zero weight & 11,183 & 5,307 & 6,333 & 10,350 & 12,448 & 4,235 \\
\hline
\end{tabular}

Notes: Estimated standard errors, clustered on GPA, are displayed in parentheses. Estimates are based on regressions including a second order polynomial in adjusted first year GPA flexible on each side of the cutoff using rectangular kernel weights and a bandwidth of 1.4. As many students with high school grades above the median are in the upper end of the overall grade distribution, the bandwidth restriction results in a substantially smaller sample size compared to students with high school grades below the median. The effect of ever being placed on probation is based on a 2SLS estimate as described in Section 5

* significant at $10 \% ; * *$ significant at $5 \% ; * * *$ significant at $1 \%$ 


\section{A Appendix}

\section{A.1 Probation letter sent to students at Campus 2}

Dear $<$ first name $>$ :

Your academic record indicates that you are experiencing challenges with your studies at xxxxxxxxxxx. As a result, you have been placed "On Probation" at the end of the xxxxxxx session. "On Probation" is an academic status applied to a student if he or she:

1. Is having difficulty achieving a term average of at least 1.7 GPA or a yearly average of 1.5 CGPA.

2. Is having difficulty meeting performance expectations and/or deadlines as outlined by the course instructor.

3. Is having difficulty achieving the minimum grades required for graduation.

A student who at the end of any session during which they are on probation has a cumulative GPA of less that 1.5 and a sessional of less that 1.7 shall be suspended therefore it is imperative that you seek assistance to improve your academic standing to avoid further sanction.

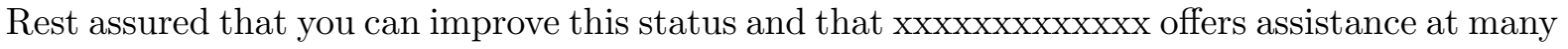
junctions. First, you can access help by making an appointment with an academic advisor in the Office of the Registrar to develop strategies to improve your academic record. Book an appointment

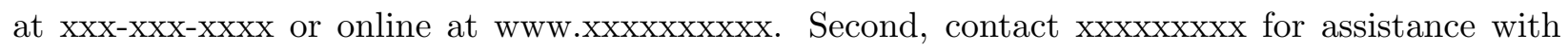
study habits, note taking, effective research, time management, study groups and peer mentors.

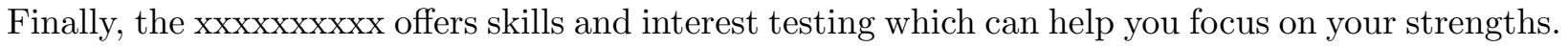

We know that you are capable to academic success, based on your academic record at admission. A good academic record is essential for entry to Limited Enrolment programs, graduate school, and professional schools. Let us review your goals and help you develop a plan to achieve them.

You have the opportunity and available support to be successful. Please utilize our services to insure your future success. 
For further information on academic status, please refer to $\operatorname{xxxxxxxx}$ of the Academic Calendar or here: http://www.Xxxxxxxxxxxxxx 